\title{
Exploring the Potential of Cell-Free Protein Synthesis for Extending the Abilities of Biological Systems
}

\author{
Khushal Khambhati ${ }^{1 \dagger}$, Gargi Bhattacharjee ${ }^{1 \dagger}$, Nisarg Gohil ${ }^{1 \neq \neq}$, Darren Braddick ${ }^{2}$, \\ Vishwesh Kulkarni ${ }^{3}$ and Vijai Singh ${ }^{\text {1*f }}$
}

${ }^{1}$ Department of Biological Sciences and Biotechnology, Institute of Advanced Research, Gandhinagar, India, ${ }^{2}$ Department of R\&D, Cementic S.A.S., Genopole, Paris, France, ${ }^{3}$ School of Engineering, University of Warwick, Coventry, United Kingdom

\section{OPEN ACCESS}

Edited by:

Pablo Carbonell,

University of Manchester,

United Kingdom

Reviewed by:

John Andrew Jones,

Miami University, United States

Jiazhang Lian,

Zhejiang University, China

*Correspondence:

Vijai Singh

vijaisingh15@gmail.com;

vijai.singh@indrashiluniversity.edu.in

†These authors have contributed equally to this work

¥Present address:

Nisarg Gohil and Vijai Singh, Department of Biosciences, School of Sciences, Indrashil University, Rajpur.

India

Specialty section:

This article was submitted to

Synthetic Biology,

a section of the journal Frontiers in Bioengineering and Biotechnology

Received: 26 June 2019 Accepted: 16 September 2019 Published: 11 October 2019

Citation: Khambhati K, Bhattacharjee G, Gohil N, Braddick D, Kulkarni V and Singh V (2019) Exploring the Potential

of Cell-Free Protein Synthesis for Extending the Abilities of Biological

Front. Bioeng. Biotechnol. 7:248 doi: 10.3389/fbioe.2019.00248
Cell-free protein synthesis (CFPS) system is a simple, rapid, and sensitive tool that is devoid of membrane-bound barriers, yet contains all the mandatory substrates, biomolecules, and machineries required for the synthesis of the desired proteins. It has the potential to overcome loopholes in the current in vivo production systems and is a promising tool in both basic and applied scientific research. It facilitates a simplified organization of desired experiments with a variety of reaction conditions, making CFPS a powerful tool in biological research. It has been used for the expansion of genetic code, assembly of viruses, and in metabolic engineering for production of toxic and complex proteins. Subsequently, CFPS systems have emerged as potent technology for high-throughput production of membrane proteins, enzymes, and therapeutics. The present review highlights the recent advances and uses of CFPS systems in biomedical, therapeutic, and biotechnological applications. Additionally, we highlight possible solutions to the potential biosafety issues that may be encountered while using CFPS technology.

Keywords: CFPS, therapeutics, biocontainment, synthetic biology, virus-like particles, high-throughput proteins

\section{INTRODUCTION}

Synthetic biology has emerged and continues to grow as a burgeoning scientific field that combines engineering principles with the biological sciences. It is defined as the "design and construction of synthetic biological parts, devices, and systems that do not exist in nature, and also includes the redesigning of natural systems for biotechnological applications" (Endy, 2005; Khalil and Collins, 2010; Qi and Arkin, 2014; Singh, 2014a). In the past decade, a number of synthetic promoters, ribosome binding sites, synthetic genes, scaffolds, and transcription factors have been designed and characterized in a wide range of organisms and cell types (Lutz and Bujard, 1997; Alper et al., 2005; Pfleger et al., 2006; Win and Smolke, 2008; Salis et al., 2009). Similarly, synthetic oscillators (Elowitz and Leibier, 2000; Stricker et al., 2008; Danino et al., 2010), toggle switches (Gardner et al., 2000; Atkinson et al., 2003), biological gates (Tamsir et al., 2011; Moon et al., 2012; Shis and Bennett, 2013; Singh, 2014b), riboregulators (Isaacs et al., 2004; Na et al., 2013), and riboswitches (Tucker and Breaker, 2005; Blount and Breaker, 2006; Patel et al., 2018) have also been designed and characterized in many organisms.

Synthetic systems have been employed in a wide range of biotechnological applications, including the sensing of cancer cells (Culler et al., 2010; Nissim and Bar-Ziv, 2010), toggle switches for controlling metabolic flux (Soma et al., 2014), oscillators for periodic gene expression (Sowa et al., 2014), T-cell controllers (Chen et al., 2010), artificial insemination (Kemmer et al., 2011), and 
many more. Synthetic chromosomes (Gibson et al., 2009, 2010; Kosuri et al., 2010; Kim et al., 2012; Hutchison et al., 2016) and multiplex automated genome engineering (Wang et al., 2009, 2012; Isaacs et al., 2011; Lajoie et al., 2013; Rovner et al., 2015) have also been developed by utilizing the synthetic biology toolboxes.

The reach of synthetic biology-mediated genome engineering has been significant in a wide range of organisms that currently include bacteria, viruses, yeast, Drosophila, zebrafish, and mammalian cells (Cong et al., 2013; DiCarlo et al., 2013; Hwang et al., 2013; Jiang et al., 2013; Mali et al., 2013; Port et al., 2014; Ren et al., 2014; Hisano et al., 2015; Jakočiunas et al., 2015; Zhu et al., 2015; Singh et al., 2017, 2018). With increasing global awareness of health, energy, and environmental issues, prioritizing the exploration and application of synthetic biology has become inevitable, given the potential options that these new sciences could offer. Recent advances in synthetic biology tools have extended their use in basic sciences, biomedical sciences, biotechnology, and industries. This expansion and development become particularly useful for accelerating the invention and innovation in the field of synthetic biology.

The daunting complexity and barrier rendered by the cell membrane prompt numerous difficulties, such as experiment being hard to standardize, incompatibility issues, and variability. To address these issues, cell-free protein synthesis (CFPS) systems, also known as in vitro protein synthesis, have emerged as a key tool that can work without the use of living cells. These systems allow one to directly control transcription, translation, and metabolism in an open source fashion (Carlson et al., 2012; Lu, 2017; Moore et al., 2017; Jiang et al., 2018; Yue et al., 2019). CFPS represents a historically important component in the field of biochemistry, duly acknowledging the pioneering effort made by Nobel laureate Eduard Buchner (Nobel Prize in Chemistry 1907) for the discovery of fermentation in yeast cell extracts (YCE) (Buchner, 1897). It has since been repurposed for the understanding of biological processes, most notably contributing to the discovery of genetic code through the use of Escherichia coli cell extract by Nirenberg and colleagues (Nirenberg and Matthaei, 1961; Matthaei et al., 1962), which ultimately led them to win and share the Nobel Prize for Physiology or Medicine in year 1968, together with Har Gobind Khorana and Robert Holley.

With the rise of synthetic biology (Gibson et al., 2010), cellfree systems have occupied a scientific niche in helping to develop the understanding of gene networks and biosynthetic pathways (Hodgman and Jewett, 2012; Koch et al., 2018). CFPS requires

Abbreviations: ATP, Adenosine triphosphate; CFPS, Cell-free protein synthesis; $\mathrm{CHO}$, Chinese hamster ovary; GM-CSF, Granulocyte macrophage colonystimulating factor; IRES, Internal ribosome entry sites; LETs, Linear expression template; MAGE, Multiplex automated genome engineering; ncAAs, Noncanonical amino acids; NMR, Nuclear magnetic resonance; nsAAs, Non-standard amino acids; pAcF, p-acetyl-L-phenylalanine; PEG, Poly-ethylene glycol; PEP, Phosphoenolpyruvate; PISA, Protein in situ array; pPaF, p-propargyloxy-Lphenylalanine; PSBS, Photosystem II subunit S; PURE, Purified recombinant elements; RF1, Release factor 1; scFv, Single-chain antibody variable fragment; sfGFP, Super folder green fluorescent protein; TX-TL, Transcription-translation; UAAs, Unnatural amino acids; USD, United States dollar; VLPs, Virus-like particles; WGE, Wheat germ extract; YCE, Yeast cell extracts; IGF-I, Insulin-like growth factor-I. the core machinery of RNA polymerase, translational apparatus (ribosomes, tRNA synthases, and translation factors), energygenerating molecules, and their cofactors, substrates, and DNA or plasmid templates for obtaining desired products. CFPS has been used for numerous experiments, including the production of proteins that need to be incorporated with toxic amino acids such as canavanine (Worst et al., 2015), incorporation of orthogonal genetic codes (Chemla et al., 2015; Des Soye et al., 2015), production of therapeutics (Zawada et al., 2011), testing of complex gene networks (Shin and Noireaux, 2012; Takahashi et al., 2015a,b), assembly of bacteriophages (Shin et al., 2012), and many more. In the present review, we highlight the recent progress and uses of CFPS in biomedical, therapeutic, industrial, and biotechnological applications.

\section{PREPARATION OF CFPS SYSTEMS}

In order to produce a protein of interest, CFPS systems use the components from crude cellular lysates of microorganisms, plants, or animals for sourcing energy and protein synthesis. Commonly used crude extracts are either of E. coli, rabbit reticulocytes, wheat germ (WGE), insect cells (Kigawa et al., 2004; Liu et al., 2005; Schwarz et al., 2007), or systems of purified recombinant elements (PURE) (Shimizu et al., 2001; Kuruma and Ueda, 2015), which are commercially available. CFPS system preparation is a simple process, where the cells of interest are grown overnight, diluted, and grown further until the optical density reaches 0.8 to 1.0 , after which cells are harvested and sonicated to extract the cell lysate. A buffer mixture augmented with necessary cofactors, energy sources, nucleotides, substrates, amino acids, and tRNAs is added to the cell extract to turn that into a CFPS and cell-free transcription-translation (TX-TL) system (Rustad et al., 2017). A comparison of the advantages of CFPS systems over live-cell counterparts is given in Table $\mathbf{1}$. Though the price of CFPS systems remains relatively high, it can be reduced by the regeneration of energy and cofactors (Kim and Swartz, 2001; Woodyer et al., 2006).

A general scheme of a CFPS system is shown in Figure 1, demonstrating a single tube experiment with appropriate buffers containing the requisite cellular lysate and DNA (linear or plasmid), along with associated energy sources, nucleotides, amino acids, salts, and cofactors, that altogether maintain the reaction to generate a product of interest. The products of CFPS can vary across numerous chemical or biological parts, including viruses, therapeutics, antibodies, chemicals, biofuels, and proteins. In producing such chemicals, there are immediate advantages that CFPS systems have over alternative in vivo systems, specifically considering the relative speed, simplicity, and effectiveness of the technology. Generally, in vivo systems are time consuming and tend to have more steps than the CFPS systems (shown in Figure 2).

Despite this, there is a desire to further reduce the cost and increase product yield of CFPS, especially considering the halflife of reaction, and accordingly researchers have invested their time and efforts to discover alternatives to the compounds that can be used as substrates for protein synthesis in CFPS systems 
TABLE 1 | Comparison of conventional live cells and CFPS systems.

\begin{tabular}{|c|c|c|}
\hline Features & Live cells & CFPS systems \\
\hline Genetic manipulation & $\begin{array}{l}\text { Complex due to cell } \\
\text { membrane barrier }\end{array}$ & $\begin{array}{l}\text { Simple due to open } \\
\text { system }\end{array}$ \\
\hline $\begin{array}{l}\text { Post-transcriptional } \\
\text { modification }\end{array}$ & Simple & Complex \\
\hline Self-replication & Simple & Complex \\
\hline Type of DNA template & Plasmids & $\begin{array}{l}\text { PCR product or } \\
\text { plasmid }\end{array}$ \\
\hline $\begin{array}{l}\text { Transmembrane } \\
\text { protein expression }\end{array}$ & Complex & Simple \\
\hline $\begin{array}{l}\text { High-throughput } \\
\text { biochemical production }\end{array}$ & Complex & Simple \\
\hline $\begin{array}{l}\text { Incorporation of } \\
\text { unnatural amino acids }\end{array}$ & Complex & Simple \\
\hline Toxic tolerance & Low & High \\
\hline $\begin{array}{l}\text { Toxic chemical } \\
\text { production }\end{array}$ & Complex & Simple \\
\hline Gene circuit testing & Complex & Simple \\
\hline $\begin{array}{l}\text { Testing of different } \\
\text { chemical } \\
\text { concentrations }\end{array}$ & Complex & Simple \\
\hline $\begin{array}{l}\text { Design-build-test } \\
\text { cycles }\end{array}$ & $1-2$ weeks & $1-2$ days \\
\hline Assembly of virus & Complex & Simple \\
\hline $\begin{array}{l}\text { Testing of orthogonal } \\
\text { gene circuits }\end{array}$ & Complex & Simple \\
\hline Protein folding & Complex & Simple \\
\hline Cost & Low & High \\
\hline Labor & More & Less \\
\hline Time & More & Less \\
\hline
\end{tabular}

(Zemella et al., 2015). The use of phosphoenolpyruvate (PEP) as an energy source leads to the rapid accumulation of phosphates due to the presence of phosphatase in the cell lysate (Zemella et al., 2015), which in turn leads to a decrease in the amount of ATP from CFPS environment (Calhoun and Swartz, 2005). Accumulation of phosphate is also known to inhibit the protein synthesis in cell-free environments owing to a reduction in the concentration of free magnesium in the reaction system (Kim and Swartz, 1999). Using glucose-6-phosphate in place of PEP as an energy source results in a higher yield of protein in a cell-free environment (Calhoun and Swartz, 2005). Mimicking the physiology of the cytoplasm is another way to increase the protein yield within cell-free systems. Jewett and Swartz (2004) demonstrated that mimicking the $\mathrm{pH}$ of cytoplasm and using appropriate buffers in reaction systems increase the yield of protein synthesis when using pyruvate as an energy source. A similar attempt was made to acquire a high yield of proteins while using a cheaper substrate. A study used fructose 1,6-bisphosphate as an energy source for protein synthesis and obtained a titer of $1.3 \mathrm{mg} / \mathrm{mL}$ of proteins with an estimated productivity cost at around 0.5 USD per milligram of protein (Kim et al., 2007).

Researchers have designed a protocol that can be easily operated by even non-experts (Levine et al., 2019). The protocol is based upon growing the E. coli cells in enriched media using baffled flask and preparing its lysate through sonication. With the addition of appropriate reagents and other substrates, the protocol designed by Levine et al. (2019) was able to give $0.9 \mathrm{mg} / \mathrm{mL}$ of super folder green fluorescent protein (sfGFP) in $5 \mathrm{~h}$ of reaction time at a cost of 21 USD per milligram of protein synthesized. A study has also been carried out that allows researchers to transcribe and translate the protein of interest in an in vitro manner using lysate of thermophilic organism named Sulfolobus solfataricus (Lo Gullo et al., 2019). The protocol allows the user to express active protein at high temperature. The optimum temperature to carry out reaction was found to be $70^{\circ} \mathrm{C}$ without the addition of exogenous components. However, the authors did conclude that the developed protocol is not yet suitable for up-scale production of recombinant protein (Lo Gullo et al., 2019). Due to high rate of protein synthesis found in Vibrio natriegens, its extract can act as a potential candidate for high rate of CFPS. Owing to this fact, a highly versatile $V$. natriegens CFPS platform was developed through sonicating the cells, thereby eliminating the need for expensive instruments. A titer of $1.6 \pm 0.05 \mathrm{mg} / \mathrm{mL}$ of sfGFP was obtained in batch mode CFPS, proving that the $V$. natriegens-based CFPS system was nearly as good as the current CFPS that E. coli offers. Upon lyophilization, the active extracts retained the biosynthesis properties and the ability to produce antimicrobial peptides (Des Soye et al., 2018). Similarly, a protocol was also developed that makes use of common lab instruments, and the cell extract can be prepared within 1-2 days using a sonicator. More than $0.26 \mathrm{mg} / \mathrm{mL}$ of the sfGFP protein was synthesized within $3 \mathrm{~h}$ of reaction setup using the designed protocol by incorporating $V$. natriegens extracts (Wiegand et al., 2019).

Conventionally, studies of membrane proteins are done by obtaining steady yields of target proteins in the form of precipitates, without using membrane-mimicking structures (Zemella et al., 2015). This results in relatively laborious purification and re-solubilization steps that can possibly change the characteristics of the target protein. Membrane-mimicking structures that include detergents (such as Triton X-100 and Digitonin), nanodiscs, and liposomes have been used to facilitate the correct folding of membrane proteins in a cell-free environment (Zemella et al., 2015). The crowding caused by high concentration of macromolecules influences the equilibrium constants and kinetic rates of the experiments including TXTL-based cell-free experiments (Minton, 2001). Considering this, Rustad et al. (2017) synthesized bacteriophages MS2, ФX174, and T7 in separate OnePot reactions using an E. coli-based cellfree TX-TL system. To mimic better physiology of cytoplasm, they examined the impact by altering the concentrations of magnesium and potassium, as well as by increasing molecular crowding with the addition of PEG 8000 (up to $4.5 \% \mathrm{wt} / \mathrm{vol}$ ), which demonstrated dramatic effects on phage synthesis. To further explore the influence of macromolecular crowding in the CFPS system, an equation has been proposed to describe the in vitro biomimicry of the crowded environment present within E. coli in desire volume of reaction mixture using its lysate (Khambhati et al., 2019a). Sun et al. (2013) have devised a novel method using E. coli BL21 Rosetta 2 strain, capable of accessing both the endogenous and exogenous cellular machinery 


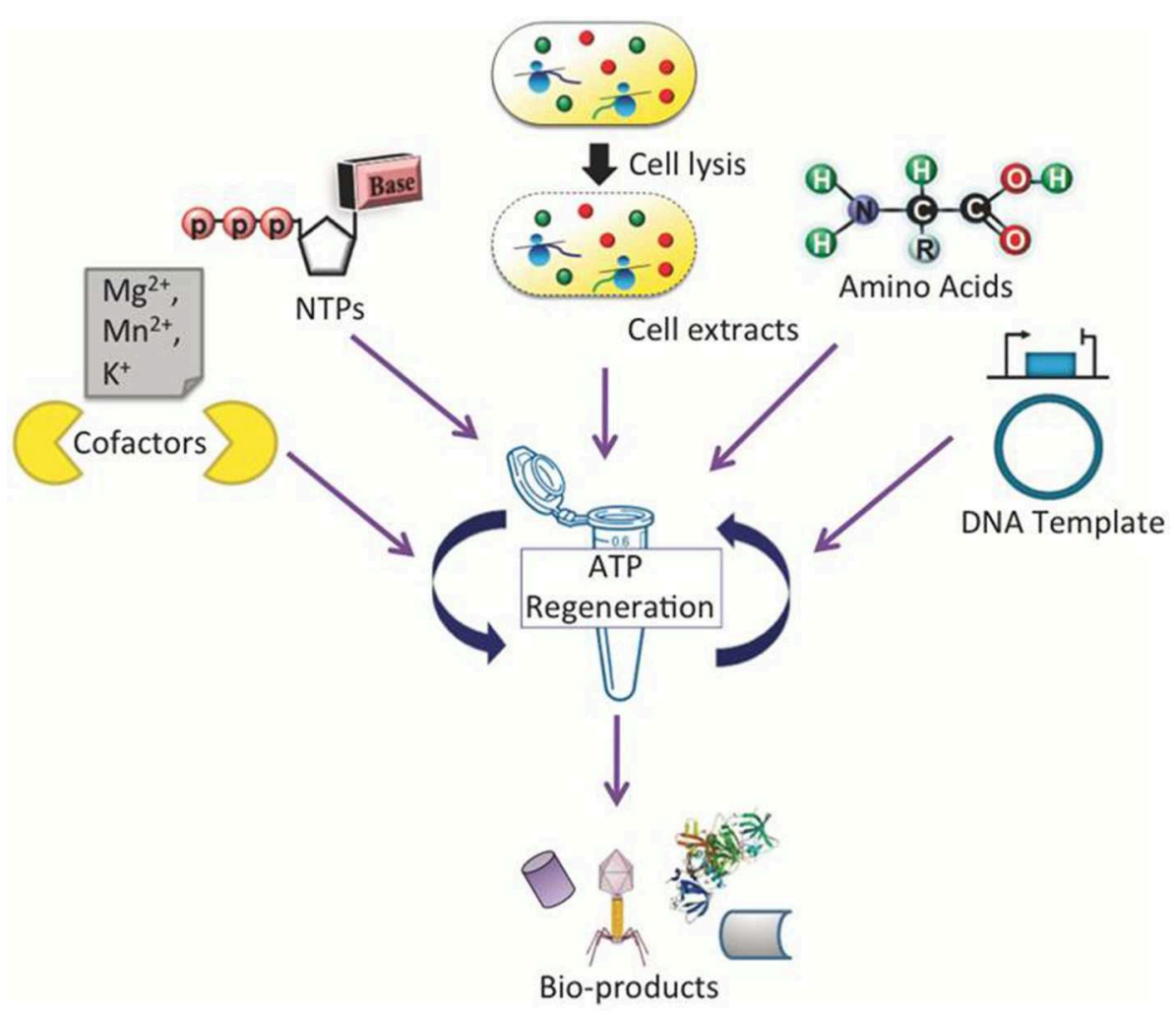

FIGURE 1 | Schematic representation of a CFPS system performed in a single tube which requires cellular lysate, energy sources, nucleotides, amino acids, salts, cofactors, linear or plasmid DNA, and water/buffer to maintain the reaction. Such a system could be used to synthesize viruses, antibodies, therapeutic and high-throughput proteins.

of E. coli for protein synthesis. They used bead beating over homogenization and sonication for cell lysis to avoid sample heating and employed the use of 3-phosphoglyceric acid as an energy source, noting higher yield than PEP and creatine phosphate. Compared to the commercially available cell-free systems, this study demonstrated a $98 \%$ cost reduction, with material costs of 0.011 USD per microliter of cell reaction, resulting in $0.75 \mathrm{mg} / \mathrm{mL}$ of GFP.

With the advancements in CFPS systems, researchers have also attempted to use non-ribosomal biosynthetic pathways for in vitro cyclic peptide production. Goering et al. (2016) used PEP as an energy source for synthesizing D-Phe-L-Pro diketopiperazine (DKP), a cyclic dipeptide. DKP was produced by cell-free co-expression of plasmids containing the GrsA and GrsB1 genes. Furthermore, E. coli BL21 Star [DE3] strain was used for preparation of cell lysates. In order to convert GrsA and GrsB1 into their functional forms, Bodipy-CoA and Sfp were added directly into the system after incubating the plasmids for $17 \mathrm{~h}$. The system was composed of a single pot experiment that rendered a DKP titer of $0.012 \mathrm{mg} / \mathrm{mL}$. The incorporation of non-canonical amino acids (ncAAs) in polypeptides imparts new functionalities and chemical properties to the target protein, but has remained a difficult task to perform in vivo due to its toxicity (Worst et al., 2016). To address this, Worst et al. (2016) created a cell-free TX-TL protocol that allows the successful incorporation of L-canavanine (in place of L-arginine) and L-hydroxy-lysine (replacing Llysine) into proteins, thus expanding the potential for novel functionalities to be added to proteins while avoiding the risks of cellular toxicity. These studies show that cell-free systems can be a valuable tool for production of complex molecules. A cost-effective OnePot PURE system has been developed, which suggest the researchers to grow 36 essential proteinproducing $E$. coli clones in a single flask and purifying them by using single Ni-NTA purification method. The normalized cost improvement of the developed method over the existing PURE system was found to be 14-fold at a cost of 0.09 USD per microliter of reaction with a titer of $0.156 \mathrm{mg} / \mathrm{mL}$ of protein (Lavickova and Maerkl, 2019).

\section{POTENTIAL APPLICATIONS OF CFPS SYSTEMS}

The productivity, cost, scale, and complexity of recombinant proteins have rapidly extended the uses and commercialization of CFPS systems (Swartz, 2006). In this section, we highlight the successes obtained with CFPS systems across numerous projects that have looked at increasing and improving the production of valuable products, including proteins, enzymes and therapeutics. 


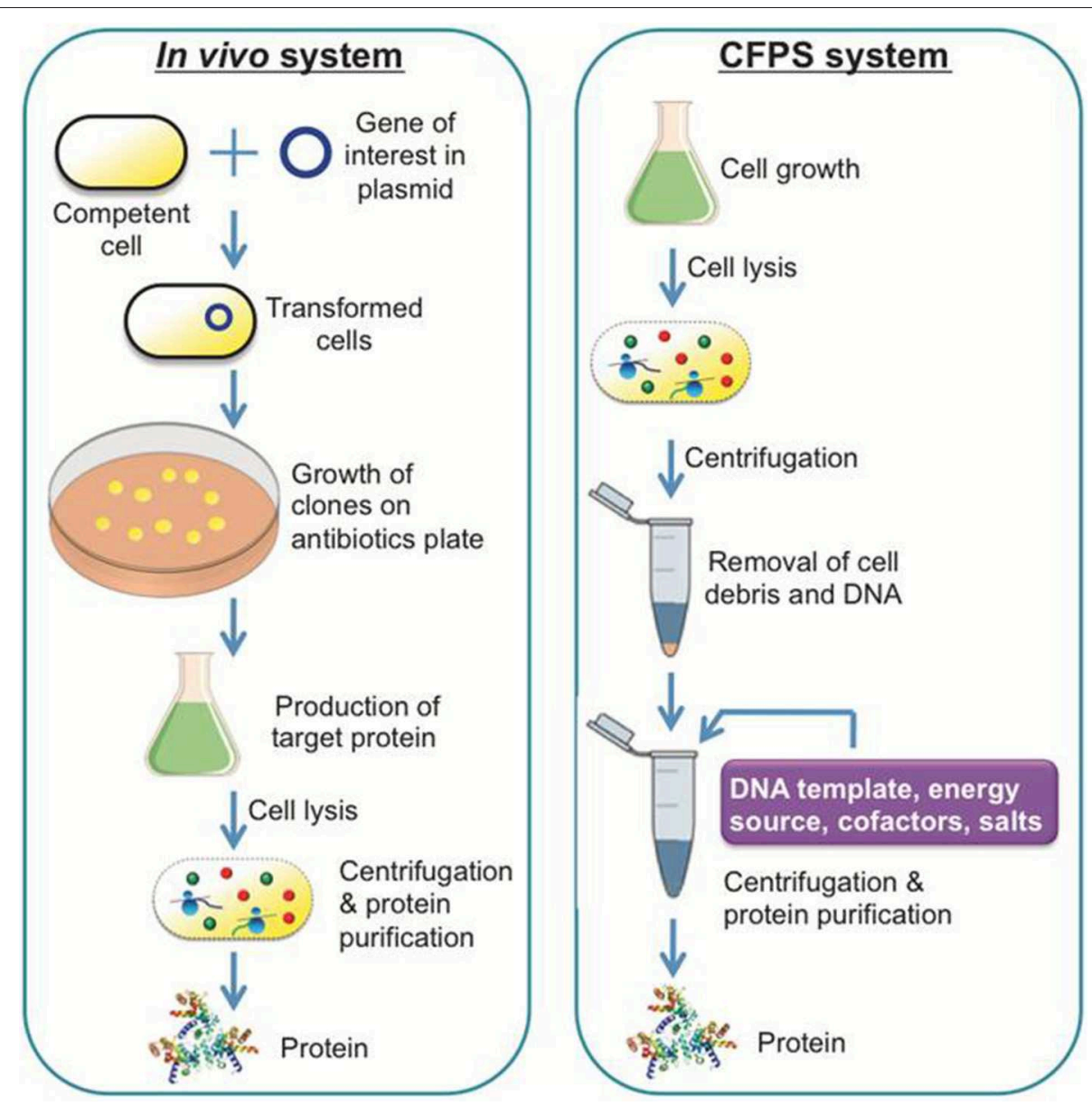

FIGURE 2 | A comparison of a conventional in vivo system and a CFPS system. The in vivo system is capable of producing recombinant proteins or therapeutic compounds like the CFPS system, although it takes more experimental steps and time to achieve the equivalent result.

The potential applications of CFPS systems are summarized in Figure 3.

\section{High-Throughput Proteins}

In the post-genomic era, high-throughput CFPS platforms have received much attention due to their numerous advantages which include (i) direct use of PCR templates to avoid exhaustive cloning steps, (ii) cost-effective reactions, (iii) potential for miniaturization as well as automation via microfluidics chips, and (iv) lack of a cell wall barrier that allows easy manipulation of reactions. The use of CFPS systems could be a better choice for labeling, through incorporation of unnatural amino acids (UAAs), which is quite useful for nuclear magnetic resonance (NMR) or X-ray crystallographic analysis (Sawasaki et al., 2002; Jin and Hong, 2018). Accordingly, CFPS has demonstrated efficiency for easy incorporation of labeled amino acids and high protein expression that allows better NMR analysis (Sawasaki et al., 2002; Morita et al., 2003; Ozawa et al., 2004; Takai et al., 2008).

CFPS systems have been used for the large-scale synthesis of protein libraries for functional genomics studies. Protein in situ arrays (PISA) have been used for quick and efficient generation of CFPS systems to study protein interaction on biochips (He and Taussig, 2007; He et al., 2008). WGE-based CFPS systems have been used for synthesizing 13,364 human proteins, creating the infrastructure for a human protein factory. Notable results from this include the finding of 58 of the 75 synthesized human phosphatase enzymes to be functional and later printing them onto glass slides to build a functional protein microarray (Goshima et al., 2008).

Chinese hamster ovary $(\mathrm{CHO})$ cell line is recognized as safe and most prominent for industrial protein production. The cell lysate of $\mathrm{CHO}$ contains microsomes and may also contain proteins including disulfide isomerase or binding immunoglobin protein that are essential for disulfide bridging and correct folding of disulfide bridged proteins. These features can be used to synthesize proteins that are difficult to express by ensuring continuous-flow cell-free systems of the $\mathrm{CHO}$ cell lysate. Optimizing the CFPS reaction conditions produced up to $0.98 \mathrm{mg} / \mathrm{mL}$ of membrane protein (Thoring et al., 2017). Apart from $\mathrm{CHO}$ cell lysate, cultured Spodoptera frugiperda 21 cells have also been used to take advantage of translocationally active 


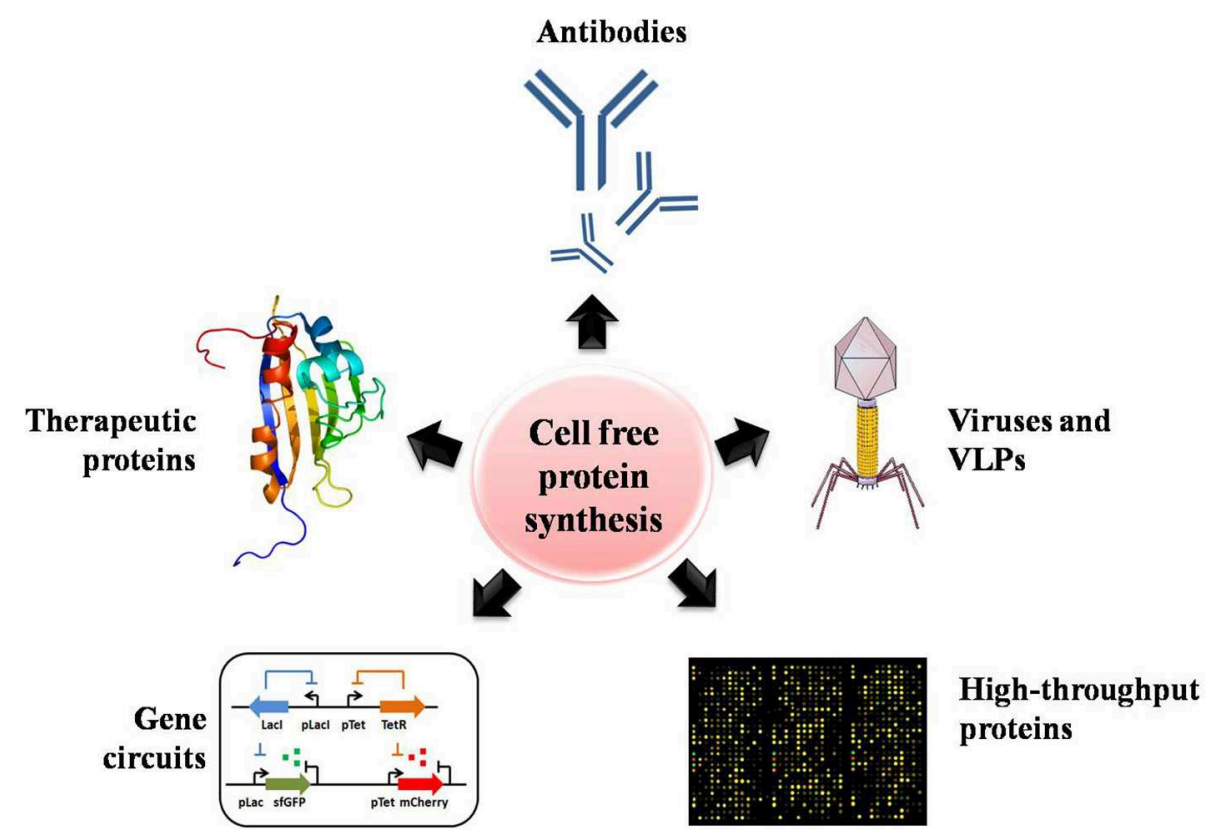

FIGURE 3 | The numerous potential applications of CFPS systems for assisting high-throughput protein production, including the production of antibodies, proteins with unnatural amino acids, therapeutics, viruses and virus-like particles, and gene circuits.

microsomes. With the combination of internal ribosome entry sites (IRES) and continuous exchange CFPS reaction protein translation, the epidermal growth factor receptor production reached up to $0.285 \mathrm{mg} / \mathrm{mL}$ (Quast et al., 2016). Similarly, 0.7 $\mathrm{mg} / \mathrm{mL}$ of the virus envelope protein (gp67) was also attained from insect cell lysates (Merk et al., 2015). CFPS systems can be further expanded for expression and testing of higher libraries in 384 well formats, allowing complex studies and highthroughput experiments to work sufficiently faster, quicker, and at a lower cost.

Protein products play a vital role in the field of medical care today. A significant proportion of proteins that are being used in biopharmaceutical and industrial fields are difficult to express, as they are often too complex and toxic, or belong to membrane proteins that are difficult to produce using living cells. Therefore, a primary goal of CFPS system is to regulate and optimize the protein production in vitro. High levels of protein toxicity can result in death of living cells during gene cloning and expression in vivo. Toxic proteins can interfere with metabolic biosynthetic pathways and tend to inhibit cell division. Therefore, they are hard to express in high amounts in vivo. A few of the highly toxic proteins have already been expressed and purified from cell-free systems, including restriction endonucleases (Goodsell, 2002), cytolethal distending toxin (Ceelen et al., 2006), and human microtubule-binding protein (Betton, 2003). Since there is no reliance on cellular growth and division, CFPS systems can be used as an alternative and excellent platform for toxin production. Membrane proteins continue to gain scientific attention due to their potential as drug targets, although in vivo overexpression of such proteins remains a critical bottleneck in research progress due to their complex structures, potential toxicity, tedious preparation, and low efficiency. A number of studies have suggested that CFPS systems can be used for overexpression of membrane proteins, with successes demonstrated for a number of membrane proteins that include the G-protein coupled receptor (Orbán et al., 2015), vaccine antigens (Welsh et al., 2012; Lu et al., 2014), and tetracycline pump TetA (Wuu and Swartz, 2008). In this regard, the non-natural and highly toxic (in the context of living cells) amino acid canavanine, an analoge of arginine that could serve as a possible antimetabolite and organic allelochemical agent, has been expressed via the CFPS system (Worst et al., 2015).

CFPS system has even been used for incorporation of UAAs using orthogonal tRNA, producing $0.9-1.7 \mathrm{mg} / \mathrm{mL}$ of soluble sfGFP variants, containing either p-azido-L-phenylalanine $(\mathrm{pAzF})$ or p-propargyloxy-L-phenylalanine (pPaF), which accumulated in the CFPS solution (Albayrak and Swartz, 2013). Correspondingly, CFPS has been used for incorporation of non-standard amino acids (nsAAs) for the generation of proteins and enzymes with novel properties, renewed structural elements, and prominent functions (Hong et al., 2014). For the cell lysate preparations, E. coli cells lacking RF1 (release factor 1), a protein known to terminate the machinery supporting translation, was used. To incorporate site-specific nsAAs, an amber suppression mechanism was used where 13 occurrences of the amber stop codon (UAG) were reassigned with synonymous ochre (UAA) codon (rEc.E13. $\Delta$ prfA) (Figure 4). The maximum production was noted to be $0.19 \pm 0.02 \mathrm{mg} / \mathrm{mL}$ of soluble sfGFP that contained either a single $\mathrm{pPaF}$ or $\mathrm{p}$-acetyl-L-phenylalanine (pAcF) in its sequence (Hong et al., 2014). In another study, the site-specific integration of UAAs was used to expand the protein diversity and proteomic code (Shrestha et al., 2014). 


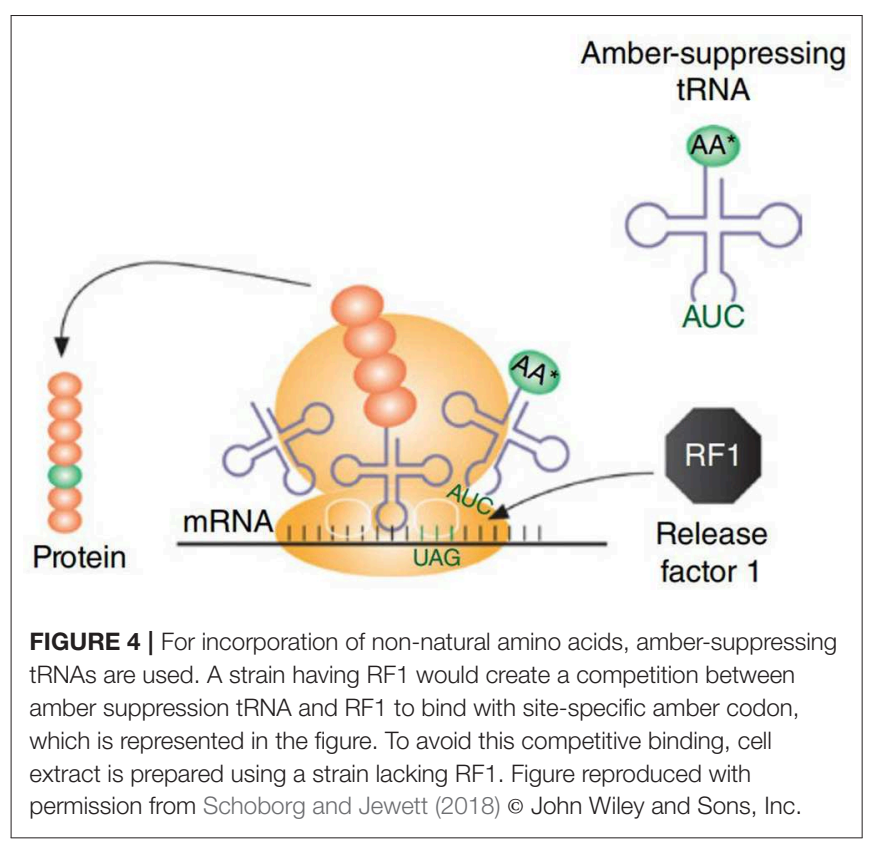

The cost consumption was reduced by $55 \%$ using alternative energy sources (such as glucose). Linear expression templates (LETs) were used for the expression and incorporation of UAAs, as using LET-based systems reduce the labor expense in comparison to in vivo or plasmid-based CFPS production. Labor expenses are reduced in terms of the steps required for production. LETs-based system requires only four steps, i.e., PCR, CFPS, purification, and analysis, whereas in vivo and plasmid-based CFPS require additional steps that include synthesis of a plasmid library, transformation into an expression strain (for in vivo CFPS), plasmid purification (for plasmid-based CFPS), and cell growth along with its maintenance (in vivo). In the same perspective, UAAs were incorporated at site-specific locations using the CFPS system of E. coli in combination with an aminoacyl-tRNA synthetase and a suppressor tRNA evolved from Methanocaldococcus jannaschii which rendered a high titer (up to $1 \mathrm{mg} / \mathrm{mL}$ ) of proteins bearing the incorporated UAAs at specific sites (Ozawa and Loh, 2014). Subsequently, the crude cell extracts of a genomically recoded E. coli strain (MCJ.559) lacking RF1 and disabled for five negative effector nuclease genes ( $r n a$, $r n b, c s d A, m a z F$, and $e n d A$ ) were used to produce $0.55 \pm 0.04$ $\mathrm{mg} / \mathrm{mL}$ of sfGFP containing $\mathrm{pAcF}$, which was further maximized to $1.3 \mathrm{mg} / \mathrm{mL}$ by using a semi-continuous system (Hong et al., 2015).

Engineering tRNAs and aminoacyl-tRNA synthetase for expansion of genetic code through the incorporation of nsAAs is another approach (Martin et al., 2018). A CFPS platform using MAGE in E. coli through the deletion of RF1 has been developed (Martin et al., 2018). This optimized platform initially obtained a titer up to $1.78 \mathrm{mg} / \mathrm{mL}$ of sfGFP, which upon extension through incorporation of 40 identical $\mathrm{pAcF}$ residues into an elastin-like polypeptide produced $0.096 \mathrm{mg} / \mathrm{mL}$ of the desired polypeptide having 98\% accuracy (Martin et al., 2018). This system could be useful for the incorporation of other UAAs for understanding the novel aspects of protein diversity and functionality. Furthermore, an effective and efficient protocol has been designed for tightly regulated addition of UAA at a particular site of protein (Gao et al., 2019). The components of orthogonal translation system were added separately and orthogonal-tRNAs were added indirectly (Gao et al., 2019).

The yield of membrane protein through cell-free expression is much less compared to non-membrane proteins (Krishnan et al., 2019). Thus, efforts have been made to increase the yield of membrane proteins through cell-free expression by designing a protocol using detergent and lipid nanodisc (Figure 5). Results have revealed that detergents such as Brij-35 and Brij-78 are suitable for solubilizing the photosystem II subunit S (PSBS) membrane protein (Krishnan et al., 2019). One of the reasons for this might be the long chain of polyoxyethylene-alkylethers present in Brij-35 and Brij-78 detergents along with their hydrophilic head that aids the solubilization of the PSBS protein. Moreover, the designed cell-free protocol facilitates the expression of PSBS protein using continuous exchange system at $30^{\circ} \mathrm{C}$ temperature with a titer of $500 \mathrm{ng} / \mu \mathrm{L}$ of the reaction system. The purification and refolding of the PSBS protein were facilitated by using $n$-dodecyl $\beta$-D-maltoside detergent (Krishnan et al., 2019).

\section{Therapeutics}

Numerous studies have stressed on the substantial functional efficiency of recombinant proteins derived from CFPS systems. CFPS has been accredited to be a viable option for the production of therapeutic proteins (Tran et al., 2018). Complex proteins such as urokinase protease and a variant of the human tissuetype plasminogen activator, containing six and nine disulfide bonds, respectively, have been produced with the help of cellfree systems using E. coli cell extracts (Kim and Swartz, 2004; Yin and Swartz, 2004). The therapeutic importance of urokinase protease relates to its activity as a thrombolytic agent that aids the treatment of thrombus-related diseases. The key role of urokinase protease is to convert plasminogen to plasmin, a step that helps to dissolve blood clots (Craik et al., 2011). Similarly, variants of tissue plasminogen activator have the potential to be used as drugs for the treatment of acute ischemic stroke (Zivin, 2009). However, the reducing activity of disulfide in cell lysate makes it difficult to form disulfide bonds in proteins. This problem can be solved by designing an adapted method in which cell extracts when treated with iodoacetamide before initiating protein synthesis reactions, abolish the reducing activity of disulfide present in the cell lysate (Kim and Swartz, 2004; Yin and Swartz, 2004). Furthermore, the use of the purified disulfide isomerase DsbC and a glutathione redox buffer in the reaction system allows the formation of active urokinase protease $(0.04 \mathrm{mg} / \mathrm{mL})$ that contains six disulfide bonds in its final expressed structure. Besides this, the human tissue-type plasminogen activator protein with increased solubility and titer (up to $0.06 \mathrm{mg} / \mathrm{ml}$ ) was attained by using Skp (an E. coli periplasmic chaperone) and organic chemicals spermidine and putrescine in the reaction system, into which few other organic chemicals were added to maintain more natural environment 
A

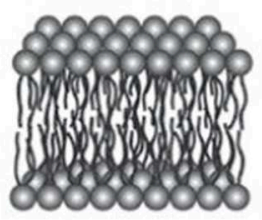

D

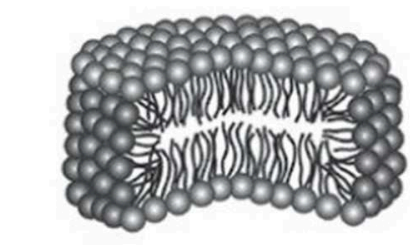

$\sim 5 \mathrm{~nm}$
B

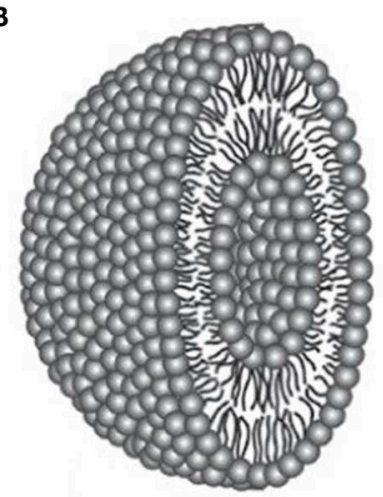

E

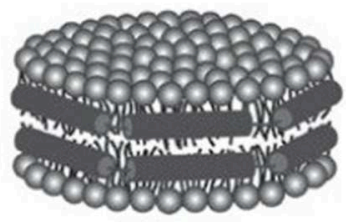

C
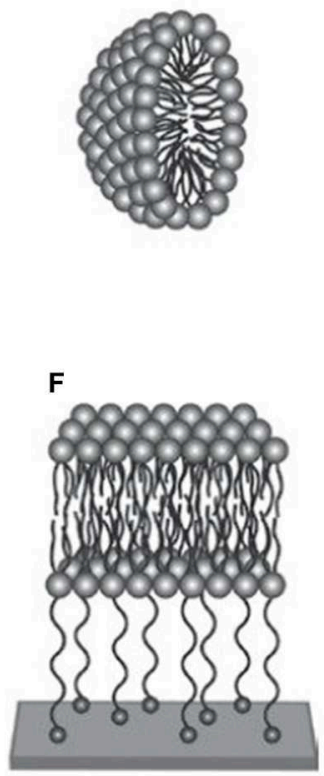

FIGURE 5 | To produce membrane proteins through CFPS platforms, several membrane-mimicking structures are used. (A) Lipid bilayer, (B) liposome, (C) micelle, (D) bicelle, (E) nanodisc, and (F) tethered bilayer lipid membrane. Figure reproduced with permission from (Schoborg and Jewett, 2018) ๑ John Wiley and Sons, Inc.

(Yin and Swartz, 2004). A summary of the therapeutic proteins that have been produced by CFPS systems is given in Table 2 .

The granulocyte macrophage colony-stimulating factor (GM-CSF) fusion proteins are potent B-cell lymphoma immunotherapeutic vaccines (Yang et al., 2005). For displaying the correct biological activity of these proteins, both GM-CSF and the B-cell lymphoma idiotype scFv should form two different disulfide bonds, and the conjugation should be at the amino terminus of GM-CSF to obtain a biologically functional product at the end (Yang et al., 2005). In a constructed CFPS system for production of active conjugates, an E. coli cell extract pretreated with iodoacetamide (IAM) containing sulfhydryl redox buffer was used and a titer of $0.043 \mathrm{mg} / \mathrm{mL}$ of $38 \mathrm{C} 13$ B-lymphocyte Id scFv conjugates was achieved (Yang et al., 2005).

The therapeutic importance of insulin-like growth factor I (IGF-I) for the treatment of some central nervous system disorders, including premenstrual syndrome (PMS) and Rett syndrome in children is immense (Costales and Kolevzon, 2016). E. coli cell lysates were used in a CFPS system to produce up to $0.4 \mathrm{mg} / \mathrm{mL}$ of IGF-I (Swartz, 2006). The human granulocytemacrophage colony-stimulating factor (rhGM-CSF) can also act as a therapeutic protein. It has been produced by Sutro Biopharma Inc. using a CFPS system hosted in a volume of 100 liters, which is one of the largest CFPS system used to date. This marks a notable instance that demonstrated the inherent potential of CFPS for the production of therapeutic proteins, and in their CFPS system, they could produce up to 0.7 $\mathrm{mg} / \mathrm{mL}$ of rhGM-CSF within $10 \mathrm{~h}$ of incubation (Zawada et al., 2011). The possible uses of rhGM-CSF include assisting cancer immunotherapy and healing of chronic wounds (Vanitha et al., 2017; Brem et al., 2018).

CFPS is an important platform that can synthesize medically important molecules rapidly in a cost-effective manner; however, the type of CFPS may affect the end result. In this context, two E. coli CFPS platforms were established, where one was cell extract-based and the other was a generic cell-free platform. The generic platform showed higher expression of therapeutic proteins, antibody fragments, and vaccines, obtaining titers of $0.71,0.23$, and $0.3 \mathrm{mg} / \mathrm{mL}$, respectively (Goerke and Swartz, 2008). Later, anti-cancer agents hGM-CSF, hG-CSF, and human Interferon alpha $2 \mathrm{~b}$ (hIFN $\alpha 2 \mathrm{~b}$ ) were produced up to $0.823 \pm 0.060,0.619 \pm 0.068$, and $0.692 \pm 0.046$ $\mathrm{mg} / \mathrm{mL}$, respectively (Goerke and Swartz, 2008). The capability to produce a number of potential vaccines was also analyzed, with CFPS-based production of murine $\mathrm{scFv}$ (Mvlvh) and human scFv (Hvlvh), along with fusion proteins of bacterial immunity protein (im9) Im9-hvlvh, mGM-Im9-mvlvh, and mGM-Im9-hvlvh, where a titer of $0.519 \pm 0.038,0.455 \pm$ $0.007,0.441 \pm 0.021,0.628 \pm 0.056$, and $0.591 \pm 0.048$ $\mathrm{mg} / \mathrm{mL}$, respectively was recorded (Goerke and Swartz, 2008). Apart from that, up to $0.4 \mathrm{mg} / \mathrm{mL}$ of the consensus interferon cIFN- $\alpha$ was also achieved with a CFPS system of $E$. coli cell lysate (El-Baky et al., 2011). The potential applications of this compound stems from its capability as an anti-cancer drug, as 
TABLE 2 | List of therapeutic proteins produced through CFPS.

\begin{tabular}{|c|c|c|c|c|}
\hline Product & Cell extract & Titer (mg/mL) & Potential application & Reference \\
\hline $\begin{array}{l}\text { Single-chain antibody variable fragment } \\
\text { against Salmonella O-antigen }\end{array}$ & Wheat Germ Extract & 0.013 & $\begin{array}{l}\text { In vivo diagnostic and } \\
\text { immunotherapeutic }\end{array}$ & Kawasaki et al., 2003 \\
\hline Urokinase protease & S30 extract (E. coli K12) & 0.04 & Treatment of thrombus & Kim and Swartz, 2004 \\
\hline $\begin{array}{l}\text { Variant of human tissue-type plasminogen } \\
\text { activator }\end{array}$ & E. coli & 0.06 & $\begin{array}{l}\text { Treatment of acute ischemic } \\
\text { stroke }\end{array}$ & Yin and Swartz, 2004 \\
\hline 38C13B lymphocyte Id scFv & E. coli (Cytomim system) & $0.043^{\star \star}$ & Lymphoma immunotherapy & Yang et al., 2005 \\
\hline Insulin-like growth factor I & E. coli & 0.4 & $\begin{array}{l}\text { Central nervous system } \\
\text { disorders (e.g., PMS, Rett } \\
\text { syndrome) }\end{array}$ & Swartz, 2006 \\
\hline $\begin{array}{l}\text { Murine granulocyte macrophage-colony } \\
\text { stimulating factor (mGM-CSF) }\end{array}$ & E. coli (KC6) & $0.854 \pm 0.054^{\star}$ & $\begin{array}{l}\text { Stimulator of systemic anti-tumor } \\
\text { immunity }\end{array}$ & $\begin{array}{l}\text { Goerke and Swartz, } \\
2008\end{array}$ \\
\hline hGM-CSF & & $0.823 \pm 0.060^{*}$ & $\begin{array}{l}\text { Cancer immunotherapy, healing } \\
\text { chronic wounds }\end{array}$ & \\
\hline $\begin{array}{l}\text { Human granulocyte colony-stimulating factor } \\
\text { (hG-CSF) }\end{array}$ & & $0.619 \pm 0.068^{*}$ & Cancer therapy & \\
\hline Human Interferon alpha 2b (hIFNa2b) & & $0.692 \pm 0.046^{\star}$ & Anti-cancer agent & \\
\hline Murine scFv (Mvlvh) & & $0.519 \pm 0.038^{\star}$ & Vaccines & \\
\hline Human scFv (Hvlvh) & & $0.455 \pm 0.007^{*}$ & & \\
\hline $\begin{array}{l}\text { Fusion protein with [bacterial immunity protein } \\
\text { (im9)] Im9-hvlvh }\end{array}$ & & $0.441 \pm 0.021^{*}$ & & \\
\hline mGM-Im9-mvlvh & & $0.628 \pm 0.056^{\star}$ & & \\
\hline mGM-Im9-hvlvh & & $0.591 \pm 0.048^{\star}$ & & \\
\hline Human consensus interferon-alpha & E. coli (S30) & 0.4 & $\begin{array}{l}\text { Anti-viral } \\
\text { and anti-tumor agents }\end{array}$ & El-Baky et al., 2011 \\
\hline $\begin{array}{l}\text { Human granulocyte-macrophage } \\
\text { colony-stimulating factor (hGM-CSF) }\end{array}$ & E. coli (KGK10) & 0.7 & $\begin{array}{l}\text { Cancer immunotherapy, healing } \\
\text { chronic wounds }\end{array}$ & Zawada et al., 2011 \\
\hline Onconase & E. coli (PANOxSP system) & 0.03 (>80\% soluble) & $\begin{array}{l}\text { Treatments of malignant } \\
\text { mesothelioma }\end{array}$ & Salehi et al., 2016 \\
\hline Botulinum toxins & $\begin{array}{l}\text { E. coli (RTS-100, RTS-500, } \\
\text { and RTS-9000 HY kits) }\end{array}$ & 1 & Botulinum vaccine & Zichel et al., 2010 \\
\hline Streptokinase & HeLa and $\mathrm{CHO}$ cell lysates & 0.50 & Thrombolytic therapy & Tran et al., 2018 \\
\hline Crisantaspase & E. coli ClearColi & 1 & Cancer therapy & Wilding et al., 2019 \\
\hline
\end{tabular}

"Total titer, "* Soluble titer.

it exhibited the anticancer effects during their in vitro studies (El-Baky et al., 2011).

Earlier, for the production of onconase, a drug for treatment of malignant mesothelioma, live E. coli cells were normally subjected to lysis and thereafter the protein was purified from inclusion bodies found in the cell pellets (Salehi et al., 2016). The issue has been addressed by a novel method that comes with an additional advantage of direct and immediate characterization of onconase without the need for laborious purification steps. The method can be used to produce up to $0.03 \mathrm{mg} / \mathrm{mL}$ of onconase in an active form with about $80 \%$ of the mass being soluble onconase (Salehi et al., 2016).

Streptokinase, an important enzyme in thrombolytic therapy, has been produced up to $0.5 \mathrm{mg} / \mathrm{mL}$, within $2.5 \mathrm{~h}$ of incubation through CFPS using HeLa and $\mathrm{CHO}$ cell lysates in such a way that the resultant protein was neither glycosylated nor had any disulfide bonds. Following an initial characterization, it was proven to be functionally efficient in terms of activity and outcome. Additionally, the use of an inert purification technology for the purification of proteins returned a better yield compared to standard affinity chromatographic technologies (Tran et al., 2018). $0.013 \mathrm{mg} / \mathrm{mL}$ of single-chain antibody variable fragment $(\mathrm{scFv})$ against Salmonella O-antigen was produced with the help of CFPS with WGE (Kawasaki et al., 2003). The obtained product may have diagnostic and immunotherapeutic applications owing to its shorter tissue clearance time and reduced immunogenicity (Anand et al., 1991).

WGE has been used for the overexpression of 124 genes from the Plasmodium falciparum genome for aiding the development of a malaria vaccine (Tsuboi et al., 2008, 2010). Out of the 124 genes, 93 genes (74\%) were expressed in the soluble form. Interestingly, it was found that native codon usage in genes resulted in a higher output when compared to using codonoptimized genes. Similarly, CFPS systems have been used for expressing the botulinum toxins, obtaining a titer up to $1 \mathrm{mg} / \mathrm{mL}$ (Zichel et al., 2010). The use of CFPS systems for production of a botulinum vaccine could eliminate the problem of codon bias, faced during the in vivo production of the recombinant 
botulinum toxin Hc chain upon using E. coli and the yeast Pichia pastoris as host organisms. In addition, a novel CFPS system based on Saccharomyces cerevisiae for protein and therapeutic production has been developed. In testing, the system managed to obtain a titer up to $0.007 \mathrm{mg} / \mathrm{mL}$ of firefly luciferase in batch reactions. In this system, factors such as expensive reagents and extraneous processing steps were eliminated (Hodgman and Jewett, 2013).

Any therapeutic protein produced from E. coli demands extensive and costly purification steps, so that the manufacturer can avoid the accumulation of $E$. coli endotoxin in the final product. The presence of endotoxin in the product can potentially lead to septic shock in the patient (Wilding et al., 2019). CFPS system generated from ClearColi ${ }^{\circledR}$ cells lysate can act as the solution for production of cell-free mediated endotoxin-free therapeutic proteins. ClearColi ${ }^{\circledR}$ cells are devoid of the endotoxin that is usually found in other E. coli cells; however, the protocol for extract preparation is slightly different as compared to other E. coli strain due to its reduced growth rate and osmolarity sensitivity (Wilding et al., 2019). A study demonstrated the production of crisantaspase from ClearColi ${ }^{\circledR}$ cells lysate containing reduced E. coli endotoxin, thus removing the costly and extensive steps for its endotoxin purification. The titer of crisantaspase obtained was comparable to that produced by the extract of E. coli BL21 strain, i.e., nearly $1 \mathrm{mg} / \mathrm{mL}$. Crisantaspase is a therapeutic protein that has been approved by FDA for cancer therapy (Wilding et al., 2019).

Glycoproteins have immense therapeutic potential, though it demands extensive as well as costly purification steps, thus posing a challenge for its production (Daniel et al., 2019). These proteins are produced in a cellular compartment called Golgi apparatus where a protein undergoes series of reactions for its glycosylation. Few of the reasons for low yield of protein synthesis through cellfree system are competing reactions and formation of undesired side products (Daniel et al., 2019). However, a cell does not face the mentioned issues as it localizes a particular reaction at a particular place through compartmentalization. Learning from the cells, a Golgi-on-chip technique was devised to achieve compartmentalization in cell-free system for specific synthesis of glycoproteins (Daniel et al., 2019).

\section{Virus and Virus-Like Particles}

Viruses are small infectious agents that are incapable of selfreproduction and use the host machinery for their propagation. Viruses can physically and metabolically remodel the host cell to establish an optimal environment for their replication (Chukkapalli et al., 2012). Viruses being able to infect a wide variety of different cell types, genetically modified viruses transporting foreign DNA have contributed greatly to the development of experimental gene therapy treatments. In comparison to in vivo studies, DNA-based CFPS systems provide a tool for the investigation of complex biological systems with a greater degree of control and freedom than other methods (Shin et al., 2012). In order to support the study of complex biological systems, Shin et al. (2012) demonstrated the replication, synthesis, and self-assembly of T7 and $\Phi$ X174 bacteriophages in vitro to establish the fact that large DNA programs can be efficiently expressed outside the cell (in their case, a test tube) through cell-free TX-TL systems. They managed to assemble around 0.1 to 1 billion functional phages with the use of $1 \mathrm{nM}$ of genome (the target DNA). The first lot of phages began to be synthesized following $1 \mathrm{~h}$ of incubation and their accumulation continued for $5 \mathrm{~h}$. It was also reported that the addition of dNTPs increased the phage production by nearly 200 fold and further investigations revealed that after the fourth hour of incubation, genomic DNA began to degrade, contributing to the observed arrest in synthesis. Even though a cytosolic lack of thioredoxin tends to impair DNA replication in vivo, it was highlighted that the absence of thioredoxin in these cell-free TXTL systems does not impede phage production (Shin et al., 2012).

VLPs are multi-protein structures, averaging between 25$100 \mathrm{~nm}$ in size, capable of self-assembly and can systematically mimic the conformation of proteins found in the native virus (Roldão et al., 2010; Carlson et al., 2012). These bionanomaterials are devoid of genetic information and as such cannot self-reproduce, but due to their ability to display highdensity viral surface proteins, they may successfully penetrate into a living cell. These particles are formed during the heterologous expression of viral proteins of the same or different viruses in a system, or spontaneously during the viral life cycle inside a cell (Chroboczek et al., 2014). These empty shells (lacking a viral genome) have the potential to be used as safe vaccines because of their ability to elicit an immune response and lack of self-replication. Stimulation of innate immunity by VLPs is facilitated through pattern recognizing receptors and toll-like receptors and the induction of a strong humoral response. This is augmented further through better uptake, processing, and presentation by antigen-presenting cells, due to highly specific structures and multimeric antigens of VLPs (Shirbaghaee and Bolhassani, 2016). Aside from vaccination, VLPs have gained interest in fields of gene therapy, drug delivery, nanotechnology, and diagnostics (Shirbaghaee and Bolhassani, 2016).

In conventional cell-based VLPs production, they were produced in vivo and their assembly was separated from the large pool of proteins ex vivo. Numerous difficulties are faced in conventional cell-based system such as poor yields, low solubility of the bacteriophage proteins, lack of post-transcriptional modifications, complications in expressing mammalian viral proteins, less stability of VLPs, costly product formation, and difficulties in the separation of morphologically similar contaminant proteins in different host systems (Pattenden et al., 2005). Accordingly, a number of studies have attempted to address these problems. In a study, Bundy et al. (2008) built an E. coli-based CFPS system for VLPs formation. Several advantages were listed over the currently used cell-based systems, including the redirection of metabolic resources more toward in vitro transcription and translation, one-step purification as well as recovery, and the removal of the laborious procedures of cell transformation. For enhancing the stability of VLPs, Bundy and Swartz (2011) controlled the redox potential of the reaction system, allowing them to be able to control the formation of disulfide bonds between capsid monomers, thus altering VLP stability. In another study, Patel and Swartz (2011) produced VLPs of bacteriophages $\mathrm{Q} \beta$ and MS2, which possessed 
the ability to be linked with azide and alkyne-containing multiple proteins that included the antibody fragment scFv and granulocyte macrophage colony-stimulating factor (GM-CSF) together, nucleic acids and poly-ethylene glycol (PEG) chains. In their experiment, they produced azide and alkyne methionine analogs on the surface of the VLPs. Proteins, nucleic acids, and PEG were each conjugated on the surface of VLPs through a $\mathrm{Cu}(\mathrm{I})$-catalyzed reaction. Their system produced $0.3 \mathrm{mg} / \mathrm{mL}$ of VLPs that included up to $85 \%$ of the methionine analogs. However, the biological activity of GM-CSF was found to be reduced by 3-5 fold after being combined with VLPs. Patel and Swartz (2011) reasoned that the molecular crowding of scFv protein on the surface of VLPs and the curvature of the VLPs prevents GM-CSF to access GM-CSF receptors, leading to a decreased bioactivity of conjugated GM-CSF.

Altogether, CFPS systems have shown great potential to overcome the currently faced problems for in vivo virus and VLPs production. Further research and better optimization of CFPS protocols are needed to improve the robustness and potency of this technique when considering the creation of virus and VLPs. In the near future, CFPS systems may well replace the currently used cell-based methods at the production scale, given the advantages that the CFPS systems have over established methods.

\section{CFPS-DRIVEN BIOCONTAINMENT}

Biocontainment is an aspect of biosafety concerning the organisms and species that can pose a risk to human health and ecology, and specifically covers their physical containment within secure areas, toward prohibiting their release into the wider community. Despite wide application and great successes, many current biocontainment strategies may not be effective enough for modern challenges, especially when concerning the release and spread of novel transgenes and/or transgenic organisms (Lee et al., 2018). Accordingly, there is a pressing need to develop new technologies to deal with biocontainment risks that threaten biosafety and biosecurity, and these technologies would ultimately serve to sharply decrease the potential severity and danger presented by genetically modified organisms. Among the many newer strategies that have been proposed to date, a number of them that involve cell-free systems have been suggested (Lee et al., 2018). The benefit of deriving proteins through CFPS systems in this way stems from their ability to remain abiotic, lacking most of the normal biotic processes of cells, while involving genes and DNA, which would be dividing, duplicating, and mutating. A number of utilities with these systems have already found success, including the biosynthesis of therapeutics and encapsulation of transcription/translation machinaries into vesicles. In all cases, the use of CFPS systems meant that the experimental process exhibited lower biosafety risk than with living systems, which may often be an undervalued aspect of cell-free systems in general.

Furthermore, the isolation of CFPS systems that are based on a xenobiological origin can restrict the spread of contamination that may result through the uptake/dispersal of transgenic materials and therefore compose another degree of security in their biocontainment level. CFPS systems have been employed to aid the incorporation of ncAAs via codon reassignment (Hong et al., 2014), which further increases biosafety through having modified organisms that have reassigned codon usage that are sufficiently alien to natural organisms so as to form a strong barrier against genetic contamination (Lee et al., 2018). This kind of xenobiological biosafety barrier is a deliberately sought out target for the field of xenobiology or xeno nucleic acids, and benefitting from use of cell-free systems underlines a clear and strong potential for these technologies to augment the biocontainment strategies of the future.

\section{CONCLUSION AND FUTURE REMARKS}

Synthetic biology is a modern and innovative scientific discipline with an aim to improve the existing industrial practices, addressing issues of poor yields and poor cost-to-product ratios, as well as the problems of current practices that inevitably damage our ecosystems through polluting acts. In any of these cases, it would be prudent to consider alternatives, and it is in synthetic biology that novel and alternative routes for the fabrication of many value-added products have been found with a compelling amount of accomplishments and an ever-fertile basis to grow future products and industries. In this context, we have reviewed and discussed CFPS, covering its numerous successes achieved to date and the wide-reaching potential for it to develop, as well as some of the necessary steps required.

CFPS systems offer a pronounced scientific impact that can drive development in many areas of high-throughput production by targeting the technology to aid the generation of valuable products that include proteins, therapeutics, and viruses/VLPs. For improving methods of protein production, CFPS systems have shown great efficiency to generate high levels of expression, purity, and yield, in addition to allowing the easier incorporation of labeled amino acids, factors that permit better NMR analysis of protein structures (Morita et al., 2003; Ozawa et al., 2004; Takai et al., 2008).

The relative ease of working with CFPS systems means that the time-consuming and laborious processes of cloning can be minimized, meaning that large-scale libraries of functional proteins can be made easier than before (Sawasaki et al., 2002; Liu et al., 2019; Rolf et al., 2019), aiding their functional study and use into biochips (He and Taussig, 2007; He et al., 2008), microarrays (Goshima et al., 2008), and continuous flow technologies (Shirokov et al., 2002). These findings indicate that CFPS systems could comfortably be expanded and used in the expression as well as testing of higher protein libraries designed for multi-well formats and experiments, allowing highly complex studies and high-throughput experiments that are assisted by this technology to work much faster that too at a lower cost, relative to current practices. Accordingly, an area of further research would be to test the full potential of CFPS systems and their applicability to assist other types of complex and highthroughput experiments.

Despite great progress in the biological domain of science, many proteins remain difficult to express in vivo, with 
issues in their complexity or toxicity as well as problems in solubilization/purification, especially for membrane proteins. We have discussed a number of difficult proteins that have already been produced with CFPS systems, including several restriction endonucleases (Goodsell, 2002), human microtubule binding protein (Betton, 2003), and cytolethal distending toxin (Ceelen et al., 2006), as well as some membrane proteins, including tetracycline pump TetA (Wuu and Swartz, 2008), vaccine antigens (Welsh et al., 2012; Lu et al., 2014), and the Gprotein coupled receptor (Orbán et al., 2015). The expression of this range of difficult proteins is highly inspiring that it could be translated toward other challenging proteins. The importance that protein and enzyme products play in modern medicine and in the biological studies cannot be understated, and accordingly, it follows that one component of the progression for this technology may simply be to apply it rigorously to the proteins that remain too difficult to study. CFPS has the potential to drive new findings in various fields that could well revolutionize many medical treatments, as well as the biomedical studies of cancer, viral infections (via human receptors), and antibiotic resistance, among many others.

The currently used cellular lysates are derived from $E$. coli, wheat germ, rabbit reticulocytes, and insect cells (Kigawa et al., 2004; Liu et al., 2005; Schwarz et al., 2007), with manufactured systems of PURE also being used (Shimizu et al., 2001; Kuruma and Ueda, 2015). It would be of great interest to use other sources of cell-free materials and substrates, especially toward addressing one of the problems in CFPS systems that concerns the post-translational modifications of products. These modifications include glycosylation, disulfide bonding, and correct protein folding. Further developments in CFPS systems would accordingly involve the testing and assay of new cellular lysates, toward identifying the best ones for all of the desired modifications possible, a project that could eventually develop into an in silico form as with numerous other protein synthesis and design assisting platforms.

Currently, cell-free systems are being used for cost-effective detection of Ebola, Zika, and dengue viral strains (Pardee et al., 2014, 2016; Gootenberg et al., 2017; Khambhati et al., 2019b), diseases that often affect poorer areas of the world with challenging accessibility issues. The invention of cheaper and portable tests that employ cell-free systems can revolutionize the manner in which these lethal diseases can be detected and dealt with, reducing their burden on human health. We believe that, in the future, CFPS will be able to address these diseases more sternly, as the damage that they do to people and communities is too high. Having realized these powerful methods for detecting these diseases, we appreciate the potential for how these can be adapted against the new viral outbreaks in future, to assist in better disease management than before. This should also be expanded for the other diseases of the world that remain difficult to diagnose and treat, where ever appropriate.

In other areas, CFPS systems have been used in a wide range of experiments, including the production of proteins that incorporate toxic amino acids such as canavanine (Worst et al.,
2015), integration of orthogonal genetic codes (Chemla et al., 2015; Des Soye et al., 2015), production of therapeutic medicines (Zawada et al., 2011), and the assembly of bacteriophages (Shin et al., 2012), among many others. Many of these experiments give clear indications on the future work that must be performed for CFPS systems. In one avenue, cellfree TX-TL systems have allowed the incorporation of Lcanavanine and L-hydroxy-lysine into proteins, opening the door for the future examination of these and other amino acid replacements. The benefit here is that, with the expansion of basic language of proteins, they are now capable of possessing novel functionalities that are otherwise toxic to living cells, opening a whole new world for modified protein and enzyme functionalities that haven't been considered before. The cell-free generation of cIFN- $\alpha$ in good yields is another exciting result, one that also demands future development to confirm the potential for it to be a novel anti-cancer treatment beyond its current proficiency in vitro (El-Baky et al., 2011).

There is an exigency for more and better drugs against the myriad forms of cancer, and this result demonstrates that CFPS systems could be well-adapted for their synthesis or for improving the existing methods. A related result that should be explored further is the cell-free synthesis of viruses/VLPs. Viruses and VLPs can be used to develop experimental gene therapy treatments, drug delivery, diagnostic tools, and nanotechnology applications (Shirbaghaee and Bolhassani, 2016). CFPS systems have demonstrated extraordinary competence for generating viruses/VLPs, exceeding some in vivo techniques, and the importance and potential of these species is such that it is likely that cell-free systems could replace cell-based methods, with a future aim of the field to extend this progress to industrial production scales (Bundy et al., 2008; Patel and Swartz, 2011).

Within all of these aspects, the use of CFPS systems has enabled biologists to advance in each of these distinct areas, discovering new results and findings. In general, we believe that this range of studies that have been benefited by cellfree expression systems offer a very promising belief that these systems can be redeployed into many other scientific studies, offering advantages that permit countless other interesting and compelling experiments to be performed, more quickly and at a lower cost, similarly to the ones that we discussed. Even in the smallest of cases, if the use of these systems can save money and time, it may well open the door for lowering the barriers to allow entry of many scientists and their projects, offering greater diversity of ideas and experiments to be possible. Lastly, we believe that the CFPS systems that we have discussed have already realized numerous successes and with the current rate that modern science and synthetic biology is growing, it is clear that novel developments and innovations must follow. We must extrapolate these successes to address many existing world issues in novel, safer, more efficient, and greener ways, to benefit the health of the planet, and ultimately remove our reliance on non-renewable and polluting sources of valuable products and energy. 


\section{AUTHOR CONTRIBUTIONS}

$\mathrm{KK}, \mathrm{GB}, \mathrm{NG}, \mathrm{DB}$, and VS have designed and written the manuscript. VK and DB have proofread and given comments as well as suggestions. VS has supervised and finalized the manuscript.

\section{REFERENCES}

Albayrak, C., and Swartz, J. R. (2013). Cell-free co-production of an orthogonal transfer RNA activates efficient site-specific non-natural amino acid incorporation. Nucleic Acids Res. 41, 5949-5963. doi: 10.1093/nar/gkt226

Alper, H., Fischer, C., Nevoigt, E., and Stephanopoulos, G. (2005). Tuning genetic control through promoter engineering. Proc. Natl. Acad. Sci. U.S.A. 102, 12678-12683. doi: 10.1073/pnas.0504604102

Anand, N. N., Mandal, S., MacKenzie, C. R., Sadowska, J., Sigurskjold, B., Young, N. M., et al. (1991). Bacterial expression and secretion of various single-chain Fv genes encoding proteins specific for a Salmonella serotype B O-antigen. J. Biol. Chem. 266, 21874-21879.

Atkinson, M. R., Savageau, M. A., Myers, J. T., and Ninfa, A. J. (2003). Development of genetic circuitry exhibiting toggle switch or oscillatory behavior in Escherichia coli. Cell 113, 597-607. doi: 10.1016/S0092-8674(03)00346-5

Betton, J. (2003). Rapid translation system (RTS): A promising alternative for recombinant protein production. Curr. Protein Pept. Sci. 4, 73-80. doi: $10.2174 / 1389203033380359$

Blount, K. F., and Breaker, R. R. (2006). Riboswitches as antibacterial drug targets. Nat. Biotechnol. 24, 1558-1564. doi: 10.1038/nbt1268

Brem, H., Howell, R., Criscitelli, T., Senderowicz, A., Siegart, N., Gorenstein, S., et al. (2018). Practical application of granulocyte-macrophage colonystimulating factor (GM-CSF) in patients with wounds. Surg. Technol. Int. 32, 61-66. Retrieved from: http://surgicaltechnology.com/32-Wound-Healing. htm\#977

Buchner, E. (1897). Alkoholische gährung ohne hefezellen. Ber. Dt. Chemi. Ges. 30, 117-124. doi: 10.1002/cber.18970300121

Bundy, B. C., Franciszkowicz, M. J., and Swartz, J. R. (2008). Escherichia colibased cell-free synthesis of virus-like particles. Biotechnol. Bioeng. 100, 28-37. doi: 10.1002/bit.21716

Bundy, B. C., and Swartz, J. R. (2011). Efficient disulfide bond formation in viruslike particles. J. Biotechnol. 154, 230-239. doi: 10.1016/j.jbiotec.2011.04.011

Calhoun, K. A., and Swartz, J. R. (2005). Energizing cell-free protein synthesis with glucose metabolism. Biotechnol. Bioeng. 90, 606-613. doi: 10.1002/bit.20449

Carlson, E. D., Gan, R., Hodgman, C. E., and Jewett, M. C. (2012). Cell-free protein synthesis: Applications come of age. Biotechnol. Adv. 30, 1185-1194. doi: 10.1016/j.biotechadv.2011.09.016

Ceelen, L. M., Decostere, A., Ducatelle, R., and Haesebrouck, F. (2006). Cytolethal distending toxin generates cell death by inducing a bottleneck in the cell cycle. Microbiol. Res. 161, 109-120. doi: 10.1016/j.micres.2005.04.002

Chemla, Y., Ozer, E., Schlesinger, O., Noireaux, V., and Alfonta, L. (2015). Genetically expanded cell-free protein synthesis using endogenous pyrrolysyl orthogonal translation system. Biotechnol. Bioeng. 112, 1663-1672. doi: 10.1002/bit.25587

Chen, Y. Y., Jensen, M. C., and Smolke, C. D. (2010). Genetic control of mammalian T-cell proliferation with synthetic RNA regulatory systems. Proc. Natl. Acad. Sci. U.S.A. 107, 8531-8536. doi: 10.1073/pnas.1001721107

Chroboczek, J., Szurgot, I., and Szolajska, E. (2014). Virus-like particles as vaccine. Acta Biochim. Pol. 61, 531-539. doi: 10.18388/abp.2014_1875

Chukkapalli, V., Heaton, N. S., and Randall, G. (2012). Lipids at the interface of virus-host interactions. Curr. Opin. Microbiol. 15, 512-518. doi: 10.1016/j.mib.2012.05.013

Cong, L., Ran, F. A., Cox, D., Lin, S., Barretto, R., Habib, N., et al. (2013). Multiplex genome engineering using CRISPR/Cas systems. Science 339, 819-823. doi: 10.1126/science.1231143

Costales, J., and Kolevzon, A. (2016). The therapeutic potential of insulin-like growth factor-1 in central nervous system disorders. Neurosci. Biobehav. Rev. 63, 207-222. doi: 10.1016/j.neubiorev.2016.01.001

\section{ACKNOWLEDGMENTS}

GB and NG acknowledge the Puri Foundation for Education in India for providing Junior Research Fellowship to carry out this work.

Craik, C. S., Page, M. J., and Madison, E. L. (2011). Proteases as therapeutics. Biochem. J. 435, 1-16. doi: 10.1042/BJ20100965

Culler, S. J., Hoff, K. G., and Smolke, C. D. (2010). Reprogramming cellular behavior with RNA controllers responsive to endogenous proteins. Science 330, 1251-1255. doi: 10.1126/science.1192128

Daniel, S., Aquino, A., DeLisa, M., Jaroentomeechai, T., Liu, H. Y., Manzer, Z., et al. (2019). Golgi-on-a-chip for the cell-free bio-nanomanufacturing of protein therapeutics. Biophys. J. 116:1a. doi: 10.1016/j.bpj.2018.11.025

Danino, T., Mondragón-Palomino, O., Tsimring, L., and Hasty, J. (2010). A synchronized quorum of genetic clocks. Nature 463, 326-330. doi: $10.1038 /$ nature 08753

Des Soye, B. J. D., Davidson, S. R., Weinstock, M. T., Gibson, D. G., and Jewett, M. C. (2018). Establishing a high-yielding cell-free protein synthesis platform derived from Vibrio natriegens. ACS Synth. Biol. 7, 2245-2255. doi: 10.1021/acssynbio.8b00252

Des Soye, B. J. D., Patel, J. R., Isaacs, F. J., and Jewett, M. C. (2015). Repurposing the translation apparatus for synthetic biology. Curr. Opin. Chem. Biol. 28, 83-90. doi: 10.1016/j.cbpa.2015.06.008

DiCarlo, J. E., Norville, J. E., Mali, P., Rios, X., Aach, J., and Church, G. M. (2013). Genome engineering in Saccharomyces cerevisiae using CRISPR-Cas systems. Nucleic Acids Res. 41, 4336-4343. doi: 10.1093/nar/ gkt135

El-Baky, N. A., Omar, S. H., and Redwan, E. M. (2011). The anti-cancer activity of human consensus interferon-alpha synthesized in cell-free system. Protein Expr. Purif. 80, 61-67. doi: 10.1016/j.pep.2011.07.003

Elowitz, M. B., and Leibier, S. (2000). A synthetic oscillatory network of transcriptional regulators. Nature 403, 335-338 doi: 10.1038/35002125

Endy, D. (2005). Foundations for engineering biology. Nature 438, 449-453. doi: $10.1038 /$ nature 04342

Gao, W., Bu, N., and Lu, Y. (2019). Efficient incorporation of unnatural amino acids into proteins with a robust cell-free system. Methods Protoc. 2:16. doi: $10.3390 / \mathrm{mps} 2010016$

Gardner, T. S., Cantor, C. R., and Collins, J. J. (2000). Construction of a genetic toggle switch in Escherichia coli. Nature 403, 339-342. doi: 10.1038/350 02131

Gibson, D. G., Glass, J. I., Lartigue, C., Noskov, V. N., Chuang, R. Y., Algire, M. A., et al. (2010). Creation of a bacterial cell controlled by a chemically synthesized genome. Science 329, 52-56. doi: 10.1126/science.1190719

Gibson, D. G., Young, L., Chuang, R. Y., Venter, J. C., Hutchison, C. A., and Smith, H. O. (2009). Enzymatic assembly of DNA molecules up to several hundred kilobases. Nat. Methods 6, 343-345. doi: 10.1038/nmeth.1318

Goering, A. W., Li, J., McClure, R. A., Thomson, R. J., Jewett, M. C., and Kelleher, N. L. (2016). In vitro reconstruction of nonribosomal peptide biosynthesis directly from DNA using cell-free protein synthesis. ACS Synth. Biol. 6, 39-44. doi: 10.1021/acssynbio.6b00160

Goerke, A. R., and Swartz, J. R. (2008). Development of cell-free protein synthesis platforms for disulfide bonded proteins. Biotechnol. Bioeng. 99, 351-367. doi: 10.1002/bit.21567

Goodsell, D. S. (2002). The molecular perspective: Restriction endonucleases. Oncologist 7, 82-83. doi: 10.1634/theoncologist.7-1-82

Gootenberg, J. S., Abudayyeh, O. O., Lee, J. W., Essletzbichler, P., Dy, A. J., Joung, J., et al. (2017). Nucleic acid detection with CRISPR-Cas13a/C2c2. Science 356, 438-442. doi: 10.1126/science.aam9321

Goshima, N., Kawamura, Y., Fukumoto, A., Miura, A., Honma, R., Satoh, R., et al. (2008). Human protein factory for converting the transcriptome into an in vitro-expressed proteome. Nat. Methods 5, 1011-1017. doi: $10.1038 /$ nmeth. 1273

He, M., Stoevesandt, O., and Taussig, M. J. (2008). In situ synthesis of protein arrays. Curr. Opin. Biotechnol. 19, 4-9. doi: 10.1016/j.copbio.2007.11.009 
He, M., and Taussig, M. J. (2007). Rapid discovery of protein interactions by cell-free protein technologies. Biochem. Soc. Trans. 35, 962-965. doi: 10.1042/BST0350962

Hisano, Y., Sakuma, T., Nakade, S., Ohga, R., Ota, S., Okamoto, H., et al. (2015). Precise inframe integration of exogenous DNA mediated by CRISPR/Cas9 system in zebrafish. Sci. Rep. 5:8841. doi: 10.1038/srep08841

Hodgman, C. E., and Jewett, M. C. (2012). Cell-free synthetic biology: thinking outside the cell. Metab. Eng. 14, 261-269. doi: 10.1016/j.ymben.2011.09.002

Hodgman, C. E., and Jewett, M. C. (2013). Optimized extract preparation methods and reaction conditions for improved yeast cell-free protein synthesis. Biotechnol. Bioeng. 110, 2643-2654. doi: 10.1002/bit.24942

Hong, S. H., Kwon, Y. C., Martin, R. W., Des Soye, B. J., de Paz, A. M., Swonger, K. N., et al. (2015). Improving cell-free protein synthesis through genome engineering of Escherichia coli lacking release factor 1. Chembiochem 16, 844-853. doi: 10.1002/cbic.201402708

Hong, S. H., Ntai, I., Haimovich, A. D., Kelleher, N. L., Isaacs, F. J., and Jewett, M. C. (2014). Cell-free protein synthesis from a release factor 1 deficient Escherichia coli activates efficient and multiple site-specific nonstandard amino acid incorporation. ACS Synth. Biol. 3, 398-409. doi: 10.1021/sb400140t

Hutchison, C. A., Chuang, R. Y., Noskov, V. N., Assad-Garcia, N., and Deerinck, E.llisman, M.H., et al. (2016). Design and synthesis of a minimal bacterial genome. Science 351:aad6253. doi: 10.1126/science.aad6253

Hwang, W. Y., Fu, Y., Reyon, D., Maeder, M. L., Tsai, S. Q., Sander, J. D., et al. (2013). Efficient genome editing in zebrafish using a CRISPR-Cas system. Nat. Biotechnol. 31, 227-229. doi: 10.1038/nbt.2501

Isaacs, F. J., Carr, P. A., Wang, H. H., Lajoie, M. J., Sterling, B., Kraal, L., et al. (2011). Precise manipulation of chromosomes in vivo enables genome-wide codon replacement. Science 333, 348-353. doi: 10.1126/science.1205822

Isaacs, F. J., Dwyer, D. J., Ding, C., Pervouchine, D. D., Cantor, C. R., and Collins, J. J. (2004). Engineered riboregulators enable posttranscriptional control of gene expression. Nat. Biotechnol. 22, 841-847. doi: 10.1038/nbt986

Jakočiunas, T., Bonde, I., Herrgård, M., Harrison, S. J., Kristensen, M., Pedersen, L. E., et al. (2015). Multiplex metabolic pathway engineering using CRISPR/Cas9 in Saccharomyces cerevisiae. Metab. Eng. 28, 213-222. doi: 10.1016/j.ymben.2015.01.008

Jewett, M. C., and Swartz, J. R. (2004). Mimicking the Escherichia coli cytoplasmic environment activates long-lived and efficient cell-free protein synthesis. Biotechnol. Bioeng. 86, 19-26. doi: 10.1002/bit.20026

Jiang, L., Zhao, J., Lian, J., and Xu, Z. (2018). Cell-free protein synthesis enabled rapid prototyping for metabolic engineering and synthetic biology. Synth. Syst. Biotechnol. 3, 90-96. doi: 10.1016/j.synbio.2018.02.003

Jiang, W., Bikard, D., Cox, D., Zhang, F., and Marraffini, L. A. (2013). RNA-guided editing of bacterial genomes using CRISPR-Cas systems. Nat. Biotechnol. 31, 233-239. doi: $10.1038 /$ nbt. 2508

Jin, X., and Hong, S. H. (2018). Cell-free protein synthesis for producing 'difficult-to-express' proteins. Biochem. Eng. J. 138, 156-164. doi: 10.1016/j.bej.2018.07.013

Kawasaki, T., Gouda, M. D., Sawasaki, T., Takai, K., and Endo, Y. (2003). Efficient synthesis of a disulphide containing protein through a batch cell-free system from wheat germ. Eur. J. Biochem. 270, 4780-4786. doi: 10.1046/j.1432-1033.2003.03880.x

Kemmer, C., Fluri, D. A., Witschi, U., Passeraub, A., Gutzwiller, A., and Fussenegger, M. (2011). A designer network coordinating bovine artificial insemination by ovulation-triggered release of implanted sperms. J. Control Release 150, 23-29. doi: 10.1016/j.jconrel.2010.11.016

Khalil, A. S., and Collins, J. J. (2010). Synthetic biology: applications come of age. Nat. Rev. Genet. 11, 367-379. doi: 10.1038/nrg2775

Khambhati, K., Bhattacharjee, G., and Singh, V. (2019b). Current progress in CRISPR-based diagnostic platforms. J. Cell. Biochem. 120, 2721-2725. doi: $10.1002 /$ jcb. 27690

Khambhati, K., Gohil, N., Bhattacharjee, G., Panchasara, H., and Singh, V. (2019a). An equation for biomimicking macromolecular crowding using Escherichia coli MG1655 strain. Biophys. Chem. 254, 106244. doi: 10.1016/j.bpc.2019.10 6244

Kigawa, T., Yabuki, T., Matsuda, N., Matsuda, T., Nakajima, R., Tanaka, A., et al. (2004). Preparation of Escherichia coli cell extract for highly productive cell-free protein expression. J. Struct. Funct. Genomics 5, 63-68. doi: 10.1023/B:JSFG.0000029204.57846.7d
Kim, D. M., and Swartz, J. R. (1999). Prolonging cell-free protein synthesis with a novel ATP regeneration system. Biotechnol. Bioeng. 66, 180-188.

Kim, D. M., and Swartz, J. R. (2001). Regeneration of adenosine triphosphate from glycolytic intermediates for cell-free protein synthesis. Biotechnol. Bioeng. 74, 309-316. doi: 10.1002/bit.1121

Kim, D. M., and Swartz, J. R. (2004). Efficient production of a bioactive, multiple disulfide-bonded protein using modified extracts of Escherichia coli. Biotechnol. Bioeng. 85, 122-129. doi: 10.1002/bit.10865

Kim, H., Han, H., Ahn, J., Lee, J., Cho, N., Jang, H., et al. (2012). Shotgun DNA synthesis for the high throughput construction of large DNA molecules. Nucleic Acids Res. 40:e140. doi: 10.1093/nar/gks546

Kim, T. W., Keum, J. W., Oh, I. S., Choi, C. Y., Kim, H. C., and Kim, D. M. (2007). An economical and highly productive cell-free protein synthesis system utilizing fructose-1, 6-bisphosphate as an energy source. J. Biotechnol. 130, 389-393. doi: 10.1016/j.jbiotec.2007.05.002

Koch, M., Faulon, J. L., and Borkowski, O. (2018). Models for cell-free synthetic biology: make prototyping easier, better and faster. Front. Bioeng. Biotechnol. 6:182. doi: $10.3389 /$ fbioe. 2018.00182

Kosuri, S., Eroshenko, N., Leproust, E. M., Super, M., Way, J., Li, J. B., et al. (2010). Scalable gene synthesis by selective amplification of DNA pools from high-fidelity microchips. Nat. Biotechnol. 28, 1295-1299. doi: 10.1038/nbt.1716

Krishnan, M., de Leeuw, T. J. J. F., and Pandit, A. (2019). Cell-free soluble expression of the membrane protein PsbS. Protein Expression Purif. 159, 17-20. doi: $10.1016 /$ j.pep.2019.02.010

Kuruma, Y., and Ueda, T. (2015). The PURE system for the cell-free synthesis of membrane proteins. Nat. Protoc. 10, 1328-1344. doi: 10.1038/nprot.2015.082

Lajoie, M. J., Rovner, A. J., Goodman, D. B., Aerni, H. R., Haimovich, A. D., Kuznetsov, G., et al. (2013). Genomically recoded organisms expand biological functions. Science 342, 357-360. doi: 10.1126/science.1241459

Lavickova, B., and Maerkl, S. J. (2019). A simple, robust, and low-cost method to produce the PURE cell-free system. ACS Synth. Biol. 8, 455-462. doi: 10.1021/acssynbio.8b00427

Lee, J. W., Chan, C. T. Y., Slomovic, S., and Collins, J. J. (2018). Nextgeneration biocontainment systems for engineered organisms. Nat. Chem. Biol. 14, 530-537. doi: 10.1038/s41589-018-0056-x

Levine, M. Z., Gregorio, N. E., Jewett, M. C., Watts, K. R., and Oza, J. P. (2019). Escherichia coli-based cell-free protein synthesis: protocols for a robust, flexible, and accessible platform technology. J. Vis. Exp. 144:58882. doi: 10.3791/58882

Liu, D. V., Zawada, J. F., and Swartz, J. R. (2005). Streamlining Escherichia coli S30 extract preparation for economical cell-free protein synthesis. Biotechnol. Prog. 21, 460-465. doi: 10.1021/bp049789y

Liu, W. Q., Zhang, L., Chen, M., and Li, J. (2019). Cell-free protein synthesis: Recent advances in bacterial extract sources and expanded applications. Biochem. Eng. J. 141, 182-189. doi: 10.1016/j.bej.2018.10.023

Lo Gullo, G., Mattossovich, R., Perugino, G., La Teana, A., Londei, P., and Benelli, D. (2019). Optimization of an in vitro transcription/translation system based on sulfolobussolfataricus cell lysate. Archaea 2019:9848253. doi: $10.1155 / 2019 / 9848253$

Lu, Y. (2017). Cell-free synthetic biology: engineering in an open world. Synth. Syst. Biotechnol. 2, 23-27. doi: 10.1016/j.synbio.2017.02.003

Lu, Y., Welsh, J. P., and Swartz, J. R. (2014). Production and stabilization of the trimeric influenza hemagglutinin stem domain for potentially broadly protective influenza vaccines. Proc. Natl. Acad. Sci. U.S.A. 111, 125-130. doi: $10.1073 /$ pnas. 1308701110

Lutz, R., and Bujard, H. (1997). Independent and tight regulation of transcriptional units in Escherichia coli via the LacR/O, the TetR/O and AraC/I1-I2 regulatory elements. Nucleic Acids Res. 25, 1203-1210. doi: 10.1093/nar/25. 6.1203

Mali, P., Yang, L., Esvelt, K. M., Aach, J., Guell, M., DiCarlo, J. E., et al. (2013). RNA-guided human genome engineering via Cas9. Science 339, 823-826. doi: 10.1126/science. 1232033

Martin, R. W., Des Soye, B. J., Kwon, Y. C., Kay, J., Davis, R. G., Thomas, P. M., et al. (2018). Cell-free protein synthesis from genomically recoded bacteria enables multisite incorporation of noncanonical amino acids. Nat. Commun. 9:1203. doi: 10.1038/s41467-018-03469-5

Matthaei, J. H., Jones, O. W., Martin, R. G., and Nirenberg, M. W. (1962). Characteristics and composition of RNA coding units. Proc. Natl. Acad. Sci. U.S.A. 48, 666-677. doi: 10.1073/pnas.48.4.666 
Merk, H., Rues, R. B., Gless, C., Beyer, K., Dong, F., Dötsch, V., et al. (2015). Biosynthesis of membrane dependent proteins in insect cell lysates: identification of limiting parameters for folding and processing. Biol. Chem. 396, 1097-1107. doi: 10.1515/hsz-2015-0105

Minton, A. P. (2001). Influence of macromolecular crowding and macromolecular confinement on biochemical reactions in physiological media. J. Biol. Chem. 276, 10577-10580. doi: 10.1074/jbc.R100005200

Moon, T. S., Lou, C., Tamsir, A., Stanton, B. C., and Voigt, C. A. (2012). Genetic programs constructed from layered logic gates in single cells. Nature 491, 249-253. doi: 10.1038/nature11516

Moore, S. J., MacDonald, J. T., and Freemont, P. S. (2017). Cell-free synthetic biology for in vitro prototype engineering. Biochem. Soc. Trans. 45, 785-791. doi: 10.1042/BST20170011

Morita, E. H., Sawasaki, T., Tanaka, R., Endo, Y., and Kohno, T. (2003). A wheat germ cell-free system is a novel way to screen protein folding and function. Protein Sci. 12, 1216-1221. doi: 10.1110/ps.0241203

Na, D., Yoo, S. M., Chung, H., Park, H., Park, J. H., and Lee, S. Y. (2013). Metabolic engineering of Escherichia coli using synthetic small regulatory RNAs. Nat. Biotechnol. 31, 170-174. doi: 10.1038/nbt.2461

Nirenberg, M. W., and Matthaei, J. H. (1961). The dependence of cell-free protein synthesis in E. coli upon naturally occurring or synthetic polyribonucleotides. Proc. Natl. Acad. Sci. U.S.A. 47, 1588-1602. doi: 10.1073/pnas.47.10.1588

Nissim, L., and Bar-Ziv, R. H. (2010). A tunable dual-promoter integrator for targeting of cancer cells. Mol. Syst. Biol. 6:444. doi: 10.1038/msb.2010.99

Orbán, E., Proverbio, D., Haberstock, S., Dötsch, V., and Bernhard, F. (2015). Cell-free expression of G-protein-coupled receptors. Methods Mol. Biol. 2015, 171-195. doi: 10.1007/978-1-4939-2230-7_10

Ozawa, K., Headlam, M. J., Schaeffer, P. M., Henderson, B. R., Dixon, N. E., and Otting, G. (2004). Optimization of an Escherichia coli system for cell-free synthesis of selectively 15N-labelled proteins for rapid analysis by NMR spectroscopy. Eur. J. Biochem. 271, 4084-4093. doi: $10.1111 / j .1432-1033.2004 .04346 . x$

Ozawa, K., and Loh, C. T. (2014). Site-specific incorporation of unnatural amino acids into proteins by cell-free protein synthesis. Methods Mol. Biol. 1118, 189-203. doi: 10.1007/978-1-62703-782-2_12

Pardee, K., Green, A. A., Ferrante, T., Cameron, D. E., DaleyKeyser, A., Yin, P., et al. (2014). Paper-based synthetic gene networks. Cell 159, 940-954. doi: 10.1016/j.cell.2014.10.004

Pardee, K., Green, A. A., Takahashi, M. K., Braff, D., Lambert, G., Lee, J. W., et al. (2016). Rapid, low-cost detection of Zika virus using programmable biomolecular components. Cell 165, 1255-1266. doi: 10.1016/j.cell.2016.04.059

Patel, K. G., and Swartz, J. R. (2011). Surface functionalization of virus-like particles by direct conjugation using azide-alkyne click chemistry. Bioconjug. Chem. 22, 376-387. doi: 10.1021/bc100367u

Patel, S., Panchasara, H., Braddick, D., Gohil, N., and Singh, V. (2018). Synthetic small RNAs: current status, challenges, and opportunities. J. Cell. Biochem. 119, 9619-9639. doi: $10.1002 /$ jcb.27252

Pattenden, L. K., Middelberg, A. P., Niebert, M., and Lipin, D. I. (2005). Towards the preparative and large-scale precision manufacture of virus-like particles. Trends Biotechnol. 23, 523-529. doi: 10.1016/j.tibtech.2005.07.011

Pfleger, B. F., Pitera, D. J., Smolke, C. D., and Keasling, J. D. (2006). Combinatorial engineering of intergenic regions in operons tunes expression of multiple genes. Nat. Biotechnol. 24, 1027-1032. doi: 10.1038/nbt1226

Port, F., Chen, H. M., Lee, T., and Bullock, S. L. (2014). Optimized CRISPR/Cas tools for efficient germline and somatic genome engineering in Drosophila. Proc. Natl. Acad. Sci. U.S.A. 111, E2967-E2976. doi: 10.1073/pnas.1405 500111

Qi, L. S., and Arkin, A. P. (2014). A versatile framework for microbial engineering using synthetic non-coding RNAs. Nat. Rev. Microbiol. 12, 341-354. doi: 10.1038/nrmicro3244

Quast, R. B., Sonnabend, A., Stech, M., Wüstenhagen, D. A., and Kubick, S. (2016). High-yield cell-free synthesis of human EGFR by IRES-mediated protein translation in a continuous exchange cell-free reaction format. Sci. Rep. 6:30399. doi: 10.1038/srep30399

Ren, X., Yang, Z., Xu, J., Sun, J., Mao, D., Hu, Y., et al. (2014). Enhanced specificity and efficiency of the CRISPR/Cas9 system with optimized sgRNA parameters in Drosophila. Cell Rep. 9, 1151-1162. doi: 10.1016/j.celrep.2014.09.044
Roldão, A., Mellado, M. C. M., Castilho, L. R., Carrondo, M. J., and Alves, P. M. (2010). Virus-like particles in vaccine development. Expert Rev. Vaccines 9, 1149-1176. doi: 10.1586/erv.10.115

Rolf, J., Rosenthal, K., and Lütz, S. (2019). Application of cell-free protein synthesis for faster biocatalyst development. Catalysts 9:190. doi: 10.3390/catal9020190

Rovner, A. J., Haimovich, A. D., Katz, S. R., Li, Z., Grome, M. W., Gassaway, B. M., et al. (2015). Recoded organisms engineered to depend on synthetic amino acids. Nature 518, 89-93. doi: 10.1038/nature14095

Rustad, M., Eastlund, A., Marshall, R., Jardine, P., and Noireaux, V. (2017). Synthesis of infectious bacteriophages in an E. coli-based cell-free expression system. J. Vis. Exp. 17:126. doi: 10.3791/56144

Salehi, A. S., Smith, M. T., Bennett, A. M., Williams, J. B., Pitt, W. G., and Bundy, B. C. (2016). Cell-free protein synthesis of a cytotoxic cancer therapeutic: onconase production and a just-add-water cell-free system. Biotechnol. J. 11, 274-281. doi: 10.1002/biot.201500237

Salis, H. M., Mirsky, E. A., and Voigt, C. A. (2009). Automated design of synthetic ribosome binding sites to control protein expression. Nat. Biotechnol. 27, 946-950. doi: 10.1038/nbt.1568

Sawasaki, T., Ogasawara, T., Morishita, R., and Endo, Y. (2002). A cell-free protein synthesis system for high-throughput proteomics. Proc. Natl. Acad. Sci. U.S.A. 99, 14652-14657. doi: 10.1073/pnas.232580399

Schoborg, J. A., and Jewett, M. C. (2018). "Cell-free protein synthesis: an emerging technology for understanding, harnessing, and expanding the capabilities of biological systems," in Synthetic Biology: Parts, Devices and Applications, eds C. Smolke, S.Y. Lee, J. Nielsen, and G. Stephanopoulos (Weinheim: John Wiley and Sons, Inc.), 309-330. doi: 10.1002/9783527688104.ch15

Schwarz, D., Junge, F., Durst, F., Frölich, N., Schneider, B., Reckel, S., et al. (2007). Preparative scale expression of membrane proteins in Escherichia coli-based continuous exchange cell-free systems. Nat. Protoc. 2, 2945-2957. doi: 10.1038/nprot.2007.426

Shimizu, Y., Inoue, A., Tomari, Y., Suzuki, T., Yokogawa, T., Nishikawa, K., et al. (2001). Cell-free translation reconstituted with purified components. Nat. Biotechnol. 19, 751-755. doi: 10.1038/90802

Shin, J., Jardine, P., and Noireaux, V. (2012). Genome replication, synthesis, and assembly of the bacteriophage T7 in a single cell-free reaction. ACS Synth. Biol. 1, 408-413. doi: 10.1021/sb300049p

Shin, J., and Noireaux, V. (2012). An E. coli cell-free expression toolbox: application to synthetic gene circuits and artificial cells. ACS Synth. Biol. 1, 29-41. doi: $10.1021 / \mathrm{sb} 200016 \mathrm{~s}$

Shirbaghaee, Z., and Bolhassani, A. (2016). Different applications of viruslike particles in biology and medicine: vaccination and delivery systems. Biopolymers 105, 113-132. doi: 10.1002/bip.22759

Shirokov, V. A., Simonenko, P. N., Biryukov, S. V., and Spirin, A. S. (2002). "Continuous-flow and continuous-exchange cell-free translation systems and reactors," in Cell-Free Translation Systems, ed A. S. Spirin (Berlin: Springer Nature), 91-107. doi: 10.1007/978-3-642-59379-6_8

Shis, D. L., and Bennett, M. R. (2013). Library of synthetic transcriptional AND gates built with split T7 RNA polymerase mutants. Proc. Natl. Acad. Sci. U.S.A. 110, 5028-5033. doi: 10.1073/pnas.1220157110

Shrestha, P., Smith, M. T., and Bundy, B. C. (2014). Cell-free unnatural amino acid incorporation with alternative energy systems and linear expression templates. N. Biotechnol. 31, 28-34. doi: 10.1016/j.nbt.2013.09.002

Singh, V. (2014a). Recent advancements in synthetic biology: current status and challenges. Gene 535, 1-11. doi: 10.1016/j.gene.2013.11.025

Singh, V. (2014b). Recent advances and opportunities in synthetic logic gates engineering in living cells. Syst. Synth. Biol. 8, 271-282. doi: 10.1007/s11693-014-9154-6

Singh, V., Braddick, D., and Dhar, P. K. (2017). Exploring the potential of genome editing CRISPR-Cas9 technology. Gene 599, 1-18 doi: 10.1016/j.gene.2016.11.008

Singh, V., Gohil, N., Ramírez García, R., Braddick, D., and Fofié, C. K. (2018). Recent advances in CRISPR-Cas9 genome editing technology for biological and biomedical investigations. J. Cell. Biochem. 119, 81-94. doi: 10.1002/jcb.26165

Soma, Y., Tsuruno, K., Wada, M., Yokota, A., and Hanai, T. (2014). Metabolic flux redirection from a central metabolic pathway toward a synthetic pathway using a metabolic toggle switch. Metab. Eng. 23, 175-184. doi: 10.1016/j.ymben.2014.02.008 
Sowa, S. W., Baldea, M., and Contreras, L. M. (2014). Optimizing metabolite production using periodic oscillations. PLoS Comput. Biol. 10:e1003658. doi: 10.1371/journal.pcbi.1003658

Stricker, J., Cookson, S., Bennett, M. R., Mather, W. H., Tsimring, L. S., and Hasty, J. (2008). A fast, robust and tunable synthetic gene oscillator. Nature 456, 516-519. doi: 10.1038/nature07389

Sun, Z. Z., Hayes, C. A., Shin, J., Caschera, F., Murray, R. M., and Noireaux, V. (2013). Protocols for implementing an Escherichia coli based TX-TL cell-free expression system for synthetic biology. J. Vis. Exp. 79:e50762. doi: $10.3791 / 50762$

Swartz, J. (2006). Developing cell-free biology for industrial applications. J. Ind. Microbiol. Biotechnol. 33, 476-485. doi: 10.1007/s10295-006-0127-y

Takahashi, M. K., Chappell, J., Hayes, C. A., Sun, Z. Z., Kim, J., Singhal, V., et al. (2015a). Rapidly characterizing the fast dynamics of RNA genetic circuitry with cell-free transcription-translation (TX-TL) systems. ACS Synth. Biol. 4, 503-515. doi: 10.1021/sb400206c

Takahashi, M. K., Hayes, C. A., Chappell, J., Sun, Z. Z., Murray, R. M., Noireaux, V., et al. (2015b). Characterizing and prototyping genetic networks with cell-free transcription-translation reactions. Methods 86, 60-72. doi: 10.1016/j.ymeth.2015.05.020

Takai, K., Sawasaki, T., and Endo, Y. (2008). Development of key technologies for high-throughput cell-free protein production with the extract from wheat embryos. Adv. Protein Chem. Struct. Biol. 75, 53-84. doi: 10.1016/S0065-3233(07)75002-7

Tamsir, A., Tabor, J. J., and Voigt, C. A. (2011). Robust multicellular computing using genetically encoded NOR gates and chemical 'wires'. Nature 469, 212-215. doi: 10.1038/nature09565

Thoring, L., Dondapati, S. K., Stech, M., Wüstenhagen, D. A., and Kubick, S. (2017). High-yield production of "difficult-to-express" proteins in a continuous exchange cell-free system based on CHO cell lysates. Sci. Rep. 7:11710. doi: 10.1038/s41598-017-12188-8

Tran, K., Gurramkonda, C., Cooper, M. A., Pilli, M., Taris, J. E., Selock, N., et al. (2018). Cell-free production of a therapeutic protein: expression, purification, and characterization of recombinant streptokinase using a $\mathrm{CHO}$ lysate. Biotechnol. Bioeng. 115, 92-102. doi: 10.1002/bit.26439

Tsuboi, T., Takeo, S., Arumugam, T. U., Otsuki, H., and Torii, M. (2010). The wheat germ cell-free protein synthesis system: a key tool for novel malaria vaccine candidate discovery. Acta Trop. 114, 171-176. doi: 10.1016/j.actatropica.2009.10.024

Tsuboi, T., Takeo, S., Iriko, H., Jin, L., Tsuchimochi, M., Matsuda, S., et al. (2008). Wheat germ cell-free system-based production of malaria proteins for discovery of novel vaccine candidates. Infect. Immun. 76, 1702-1708. doi: 10.1128/IAI.01539-07

Tucker, B. J., and Breaker, R. R. (2005). Riboswitches as versatile gene control elements. Curr. Opin. Struct. Biol. 15, 342-348. doi: 10.1016/j.sbi.2005.05.003

Vanitha, S., Chaubey, N., Ghosh, S. S., and Sanpui, P. (2017). Recombinant human granulocyte macrophage colony stimulating factor (hGM-CSF): possibility of nanoparticle-mediated delivery in cancer immunotherapy. Bioengineered 8, 120-123. doi: 10.1080/21655979.2016.1212136

Wang, H. H., Huang, P. Y., Xu, G., Haas, W., Marblestone, A., Li, J., et al. (2012). Multiplexed in vivo His-tagging of enzyme pathways for in vitro single-pot multienzyme catalysis. ACS Synth. Biol. 1, 43-52. doi: 10.1021/sb3000029

Wang, H. H., Isaacs, F. J., Carr, P. A., Sun, Z. Z., Xu, G., Forest, C. R., et al. (2009). Programming cells by multiplex genome engineering and accelerated evolution. Nature 460, 894-898. doi: 10.1038/nature08187

Welsh, J. P., Lu, Y., He, X. S., Greenberg, H. B., and Swartz, J. R. (2012). Cellfree production of trimeric influenza hemagglutinin head domain proteins as vaccine antigens. Biotechnol. Bioeng. 109, 2962-2969. doi: 10.1002/bit.24581

Wiegand, D. J., Lee, H. H., Ostrov, N., and Church, G. M. (2019). Cell-free protein expression using the rapidly growing bacterium Vibrio natriegens. J. Vis. Exp. 145, e59495. doi: $10.3791 / 59495$
Wilding, K. M., Hunt, J. P., Wilkerson, J. W., Funk, P. J., Swensen, R. L., Carver, W. C., et al. (2019). Endotoxin-free E. coli-based cell-free protein synthesis: Pre-expression endotoxin removal approaches for on-demand cancer therapeutic production. Biotechnol. J. 14:e1800271. doi: 10.1002/biot.2018 00271

Win, M. N., and Smolke, C. D. (2008). Higher-order cellular information processing with synthetic RNA devices. Science 322, 456-460. doi: 10.1126/science.1160311

Woodyer, R. D., Johannes, T. W., and Zhao, H. (2006). Regeneration of cofactors for enzyme biocatalysis. Enzyme Technol. 83:101. Retrieved from: https://pdfs. semanticscholar.org/2e41/1c53a1728837cbdb5f40ca13bbb509e43e6a.pdf

Worst, E. G., Exner, M. P., De Simone, A., Schenkelberger, M., Noireaux, V., Budisa, N., et al. (2015). Cell-free expression with the toxic amino acid canavanine. Bioorg. Med. Chem. Lett. 25, 3658-3660. doi: 10.1016/j.bmcl.2015.06.045

Worst, E. G., Exner, M. P., De Simone, A., Schenkelberger, M., Noireaux, V., Budisa, N., et al. (2016). Residue-specific incorporation of noncanonical amino acids into model proteins using an Escherichia coli cell-free transcription-translation system. J. Vis. Exp. 114:e54273. doi: 10.3791/ 54273

Wuu, J. J., and Swartz, J. R. (2008). High yield cell-free production of integral membrane proteins without refolding or detergents. Biochim. Biophys. Acta 1778, 1237-1250. doi: 10.1016/j.bbamem.2008.01.023

Yang, J., Kanter, G., Voloshin, A., Michel-Reydellet, N., Velkeen, H., Levy, R., et al. (2005). Rapid expression of vaccine proteins for B-cell lymphoma in a cell-free system. Biotechnol. Bioeng. 89, 503-511. doi: 10.1002/bit.20283

Yin, G., and Swartz, J. R. (2004). Enhancing multiple disulfide bonded protein folding in a cell-free system. Biotechnol. Bioeng. 86, 188-195. doi: 10.1002/bit.10827

Yue, K., Zhu, Y., and Kai, L. (2019). Cell-free protein synthesis: chassis toward the minimal cell. Cells 8, 315. doi: 10.3390/cells8040315

Zawada, J. F., Yin, G., Steiner, A. R., Yang, J., Naresh, A., Roy, S. M., et al. (2011). Microscale to manufacturing scale-up of cell-free cytokine production-A new approach for shortening protein production development timelines. Biotechnol. Bioeng. 108, 1570-1578. doi: 10.1002/bit.23103

Zemella, A., Thoring, L., Hoffmeister, C., and Kubick, S. (2015). Cell-free protein synthesis: pros and cons of prokaryotic and eukaryotic systems. Chembiochem 16, 2420-2431. doi: 10.1002/cbic.201500340

Zhu, W., Lei, R., Le Duff, Y., Li, J., Guo, F., Wainberg, M. A., et al. (2015). The CRISPR/Cas9 system inactivates latent HIV-1 proviral DNA. Retrovirology 12, 22. doi: 10.1186/s12977-015-0150-Z

Zichel, R., Mimran, A., Keren, A., Barnea, A., Steinberger-Levy, I., Marcus, D., et al. (2010). Efficacy of a potential trivalent vaccine based on Hc fragments of botulinum toxins A, B, and $\mathrm{E}$ produced in a cell-free expression system. Clin. Vaccine Immunol. 17, 784-792. doi: 10.1128/CVI. 00496-09

Zivin, J. A. (2009). Acute stroke therapy with tissue plasminogen activator (tPA) since it was approved by the US Food and Drug Administration (FDA). Ann. Neurol. 66, 6-10. doi: 10.1002/ana.21750

Conflict of Interest: The authors declare that the research was conducted in the absence of any commercial or financial relationships that could be construed as a potential conflict of interest.

Copyright (c) 2019 Khambhati, Bhattacharjee, Gohil, Braddick, Kulkarni and Singh. This is an open-access article distributed under the terms of the Creative Commons Attribution License (CC BY). The use, distribution or reproduction in other forums is permitted, provided the original author(s) and the copyright owner(s) are credited and that the original publication in this journal is cited, in accordance with accepted academic practice. No use, distribution or reproduction is permitted which does not comply with these terms. 